S Wusek, Gary L

$5 y 9 \cdot 7557$ bopulation

friewa cenlo:y of white-

$19 ! 1$ talleidece in

northwastern

Aontalla

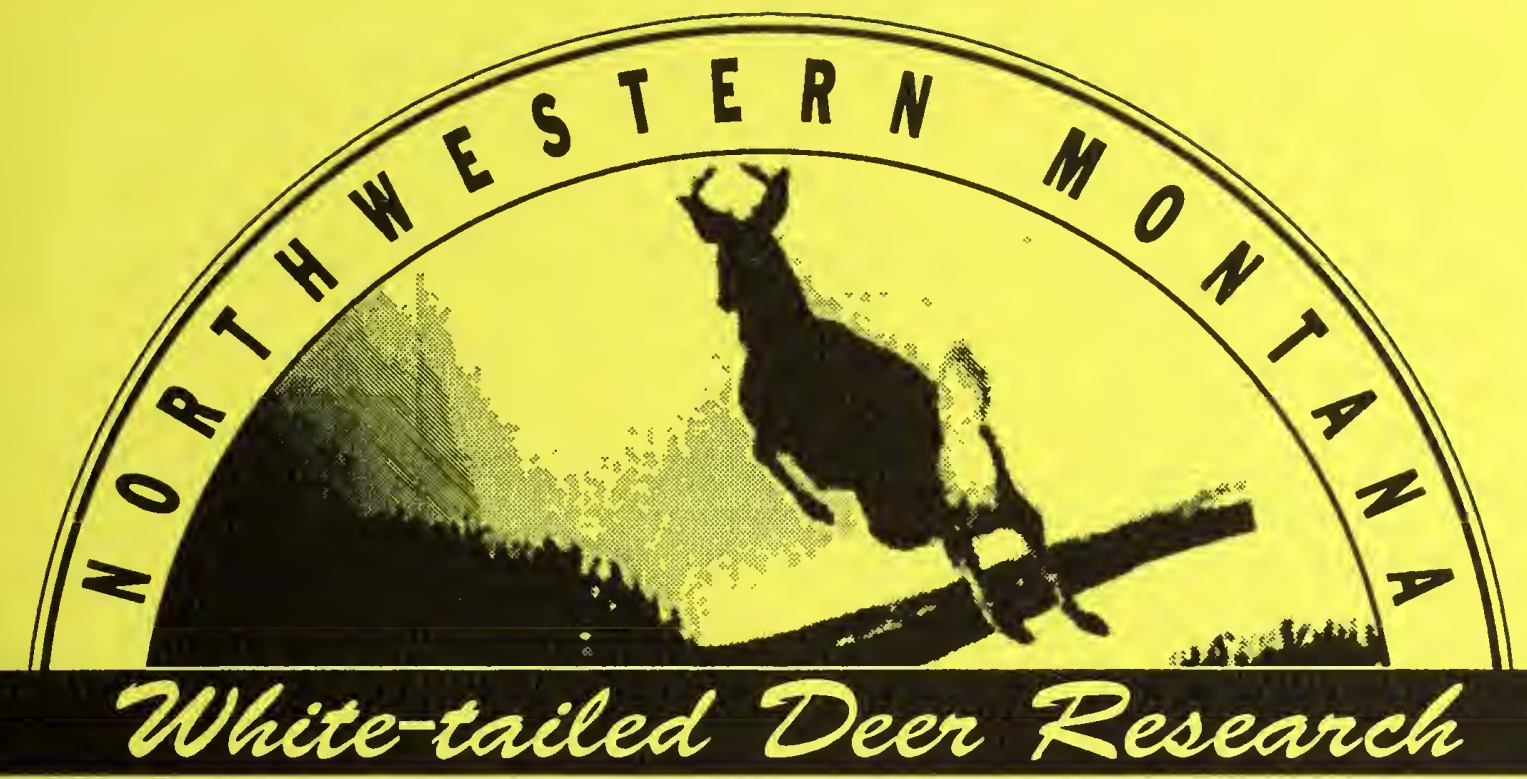

IS91 1 PROGRESS REPORT

STATE DOCUMENTS COLLECTIO:

\title{
APR 031992
}

MONTANA STATE LIBRARY

1515 E. 6th AVE.

HELENA, MONTANA 59620

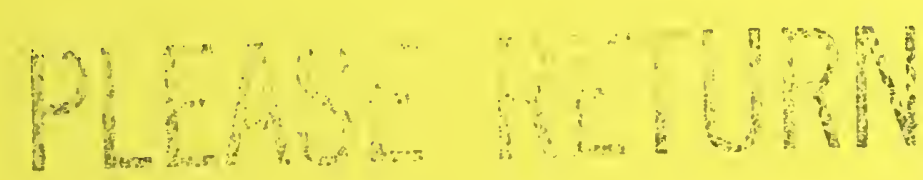


$\begin{array}{ll}\text { LE MONTANA STATE LIBRARY } & \text { S 599.7357F2pewd 1991 c.1 Dusek }\end{array}$

$\mathrm{kn}, 01998$

Population ecology of white-1 Dusek

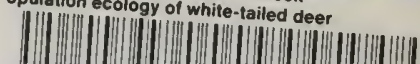

3086400076604

mR - i 1539 
STATE: Montana

PROJECT NO: $\quad$ W-100-R-4

ELEMENT: II TITLE: Big Game

SUBPROJECT NO: 2 TITLE: Research and Technical Services

STUDY: $\quad$ BG-1

TITLE: Deer

JOB NO: $\quad 10$

TITLE: $\quad$ Population Ecology of

White-tailed Deer in

Northwestern Montana

Period Covered: July 1, 1990 - June 30, 1991

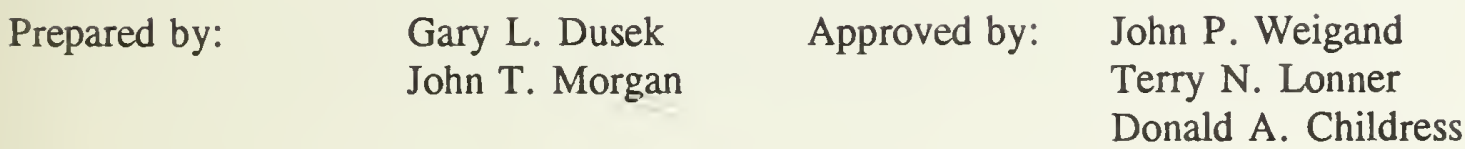

Since this is a Progress Report only, results presented herein are not necessarily final and may be subject to change. For this reason, the information contained in this report may not be published or used for other purposes without permission of the Director. 


\section{ACKNOWLEDGMENTS}

Our research effort during this report period required the assistance and cooperation of numerous individuals within the Montana Department of Fish, Wildlife and Parks. The assistance of the U.S. Forest Service (USDA) and Montana State University has contributed significantly to this effort. We thank numerous volunteers for their assistance with field work. special thanks are extended to Leonard Howke and Herb Johnson for their dedication and help throughout the past year. Our gratitude also is extended to private landowners who have granted access to their property. 
A study of population ecology of white-tailed deer (Odocoileus virginianus), initiated in the Tally Lake and Fortine Ranger Districts of northwestern Montana during January 1988, continued through the year ending 30 June 1991. Population data gathered to date are summarized prior to implementing an experimental harvest regime to determine the effects of increased harvest of antlerless deer on population trend and dynamics. During autumn 1990, 287 whitetails from the study area were examined at check stations to determine composition by sex and age and trend in physical condition. An additional 139 deer were captured and marked on winter ranges in 1991 and 10 were captured on summer ranges. Three camera surveys were conducted on winter ranges during December 1990 through March 1991. Population surveys using a remote camera system were continued to estimate of numbers of deer on winter range and determine herd composition. 
To develop techniques for estimating population parameters, to determine basic biological and ecological parameters for white-tailed deer in coniferous forests of northwestern Montana and to relate those parameters to characteristics of individual habitats and potentially limiting factors, including:

a) physical and biological characteristics of individual habitats;

b) interactions between changing environmental conditions and population characteristics; and,

c) hunting, land use practices, and other human-related factors.

\section{INTRODUCTION}

White-tailed deer are the most abundant and widely distributed big game species in Region 1 accounting for about $73 \%$ of the region's total annual deer harvest (Dusek 1989). Current perception holds that whitetail numbers in northwestern Montana have steadily increased over the past 16 years. Trend in annual harvest of antlered deer (Fig. 1) supports that hypothesis. Although a series of mild winters and subtle habitat changes associated with past forest management practices are most commonly credited for the increases, causes have not been directly or empirically determined. The increases have also occurred concomitant with a relatively conservative harvest regime for antlerless deer that resulted in proportionately fewer antlerless deer harvested since 1975 (Fig. 1). A harvest regime to double the current number of antlerless deer harvested in one of 2 hunting districts will be implemented in 1991 to test hypotheses regarding the effects of hunter harvest on populations of white-tailed deer in northwestern Montana. Determining population response to hunter harvest strategies is one of 3 primary goals of this project (Dusek 1989).

The purpose of this experimental design is to develop harvest management guidelines for white-tailed deer in northwest Montana. Objectives associated with this goal are: (1) to monitor natural mortality rates and contrast them between populations with high and low harvest of antlerless deer; (2) to monitor the effects of harvest manipulation on population trend, structure, condition, and productivity; and, (3) to monitor mortality of antlered bucks and effects of antlerless regulations on trend in buck harvest. 


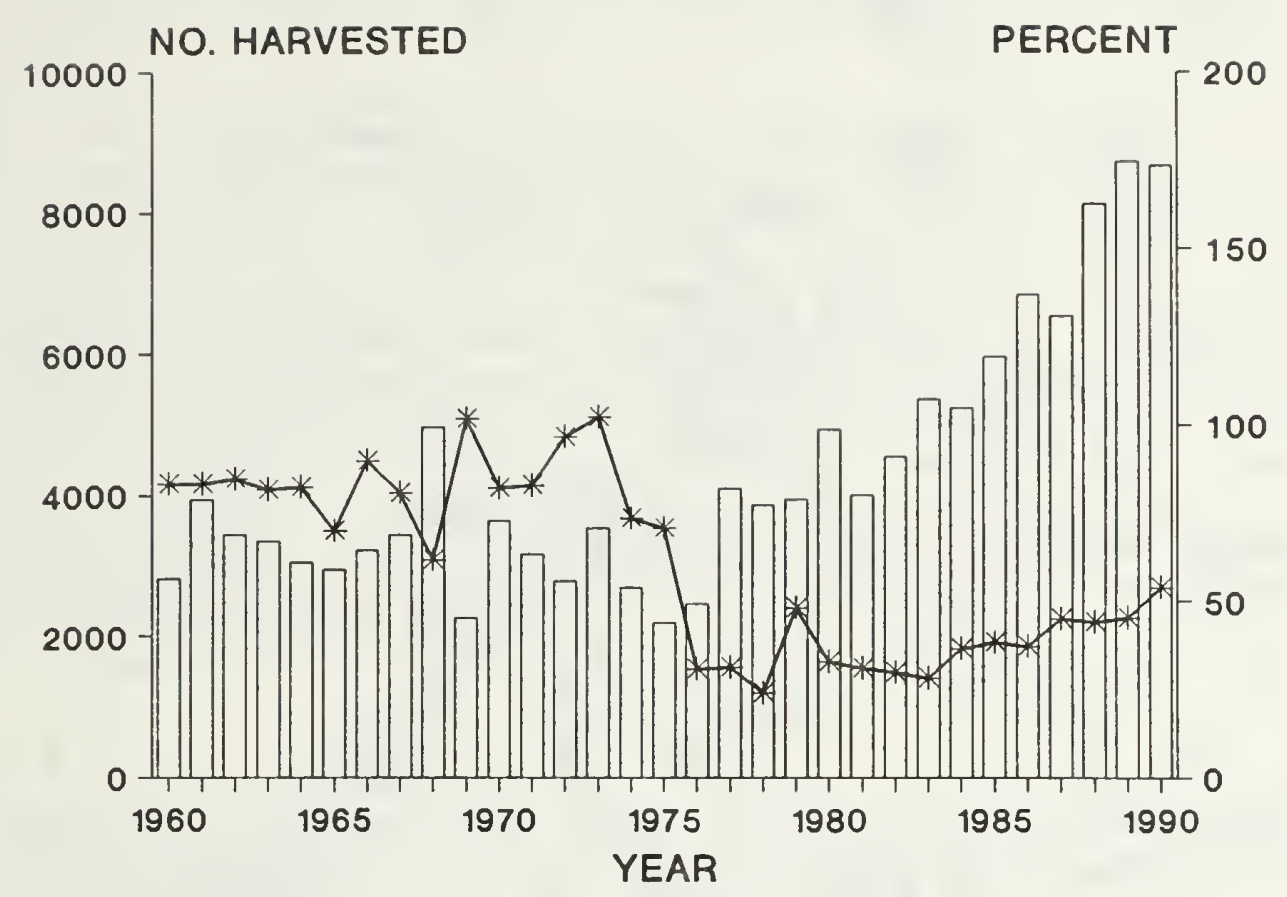

Figure 1. Northwest Montana (Region 1) white-tailed deer harvest, 1960-90. Bars represent antlered buck harvest and line represents antlerless harvest expressed as a percent of the buck harvest.

Deployment of self-activating cameras to aid in evaluation of population parameters and spatial distribution of white-tailed deer in the Salish Mountains also is described in this report. The purpose of the camera technique was to solve the problem of observability in closed canopy forest and obtain useable data throughout the diel period under all weather conditions.

\section{STUDY AREA}

Study areas include portions of the Flathead (FNF) and Kootenai (KNF) National Forests and surrounding state and private lands in the Salish Mountains (Fig. 2) and were described previously (Dusek 1989, Dusek and Morgan 1990). The portion of the Tally Lake District (FNF) under investigation occurs in hunting district 102:; a portion of the Fortine District (KNF), that includes the area around Murphy-Dickey Lakes, occurs in hunting district 101; and, a portion of hunting district 110 


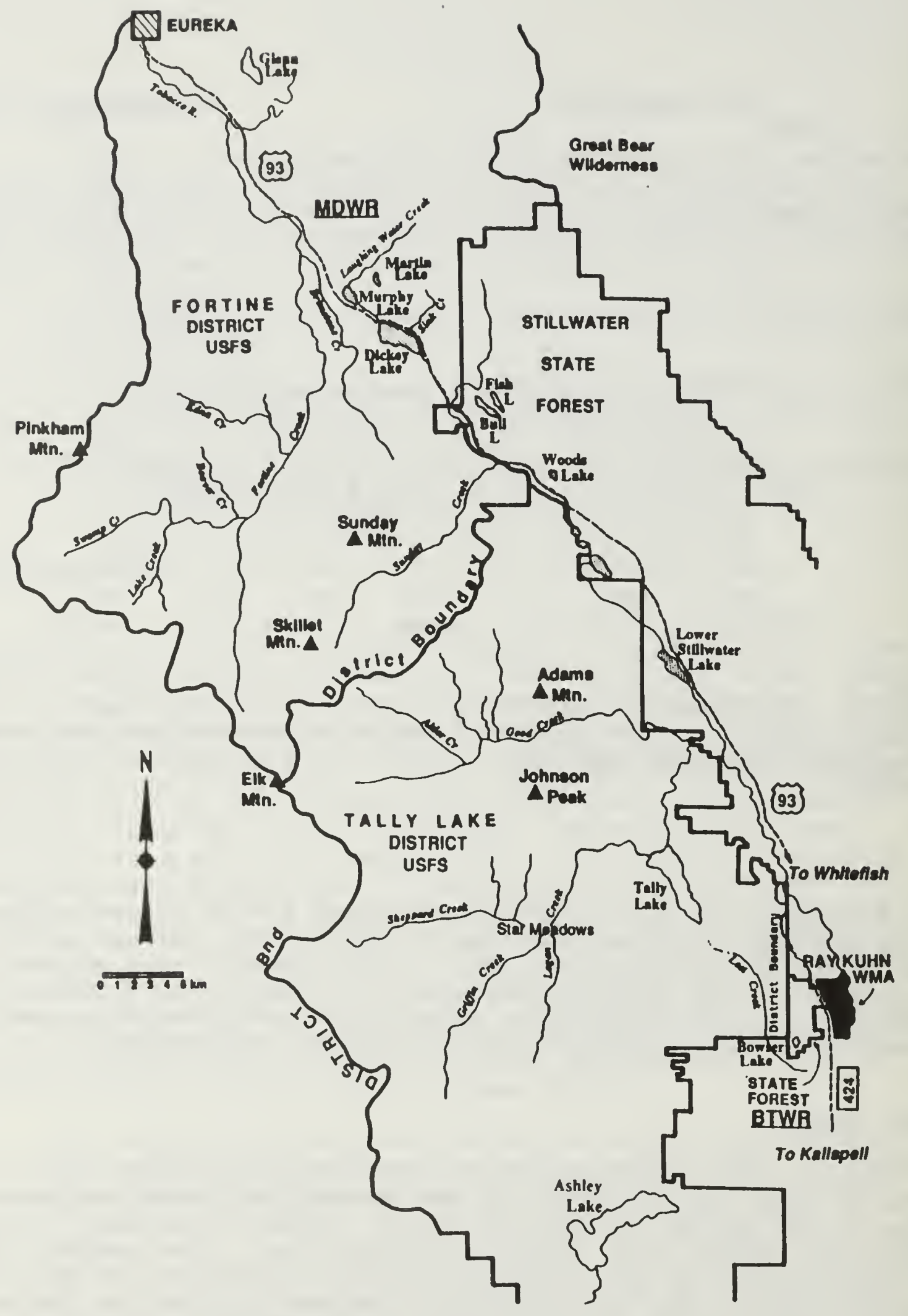

Figure 2. The Salish Mountain study area including the BowserTally Lakes winter range (BTWR) and Murphy-Dickey Lakes winter range (MDWR) . 
lying west of the Whitefish Range on the stillwater state Forest provides summer range for some deer that winter near MurphyDickey Lakes.

Timbered lands in the Tally Lake and Fortine Ranger Districts are predominantly second growth forest and are intensively managed for timber production. Habitat description follows Pfister et al. (1977). Winter ranges include comparatively dry sites below 1,100 $\mathrm{m}$ in elevation occupied by the Pseudotsuga menziesii/Symphoricarpos albus h.t. Summer ranges primarily include lower subalpine habitat types of the Abies lasiocarpa series with the P.m./Calamagrostis rubescens h.t. occupying drier, southerly exposures. Many of the upper drainages of the Salish Range are occupied by a Pinus contorta/Xerophyllum tenax c.t. Riparian sites include streams with yearlong surface flow and sloughs and potholes locally abundant in the uplands.

\section{METHOD8}

All trapping was facilitated with Clover traps (Clover 1954). Capture and handling procedures, as described previously (Dusek 1989), included assigning an age, obtaining a blood sample, and measuring heart girth of each captured deer. Maintaining samples of radio-collared deer emphasized equipping animals of known age rather than assigned age with transmitters. For example, most female deer equipped with radio collars during winter 1991 were fawn or yearling animals or older recaptured deer that were fawns or yearlings at initial capture in previous years.

Remote camera surveys, employing cameras with passive infrared (PIR) sensors, were used on the BTWR during early and late winter 1990-91 and on MDWR during late winter only. The camera was a $35 \mathrm{~mm}$ olympus Infinity model with built-in flash, automatic film advance, and capable of printing time and/or date on a photograph. Shutter release was triggered by a PIR heat sensor powered with a wet cell 12-volt battery. These components were housed in a modified 50-cal. ammunition box. Each camera unit was mounted on a tree approximately $2.5 \mathrm{~m}$ above the ground. E-6 100 ASA color slide film was used.

Units were deployed in 1990-91 on BTWR and MDWR as previously described (Dusek and Morgan 1990). During the early winter survey at BTWR, half the camera sites were baited with anise oil to determine the effect of baiting on daily rates of visitation by deer.

Procedures for summarizing and analyzing data from camera surveys were previously described by Dusek and Morgan (1990) and Dusek and Mace (1991). A capture-resight technique using a Monte 
Carlo simulation (Minta and Mangel 1989) and data from late winter camera surveys at BTWR were used to estimate numbers of deer on a $26-\mathrm{km}^{2}$ portion of winter range. A maximum likelihood estimate (MLE) and 95\% likelihood interval were derived from 10,000 iterations of the Monte Carlo simulation. The model required identification of marked individuals and assumed heterogeneity in observability among individuals. Minimum number of marked deer in the survey area was determined from monitoring distribution of radio-collared deer, and visual sightings of neckbanded deer from snowmobile routes and camera sessions.

Fixed-wing aerial surveys were conducted during all months to electronically locate radio-collared deer. Herd composition and the proportion of the population marked were determined from classification while cruising roads on the Tally Lake summer range during July and August 1990 and the BTWR by snowmobile during February and March 1991.

During the 1990 general big game hunting season, 287 harvested whitetails were examined at check stations to determine condition and composition by sex and age. Assignment of age was based on tooth replacement and wear for all deer (Severinghaus 1949) and with counts of cementum annuli (Gilbert 1966) from a middle incisor extracted from those assigned ages $\geq 2$ years (Matson's Lab, Milltown, MT). Length of the diastema was measured on all deer, and antler measurements, including length and diameter of the main beam and number of points, were taken from all males of ages $\geq 1$ year.

Pellet group transects were run during April 1991 as previously described (Dusek 1989, Dusek and Morgan 1990) using the rationale of Longhurst and Connolly (1982) and the analytical procedures of Davis (1982). Sampling intensity was maintained at 50 1-milliacre circular plots per transect for a desired level of precision (Dusek and Morgan 1990). Individual transects were placed within 13 randomly selected $1-\mathrm{km}^{2}$ quadrats for a total of 650 sampled plots.

Estimates of survival among radio-collared females of ages $\geq 1$ year and males $\geq 2$ years followed Heisey and Fuller (1985) using the software MICROMORT. Three time intervals (prehunt, rifle hunt, and posthunt) as previously described (Dusek and Morgan 1990) were used in which probability of daily survival was assumed constant throughout each period (Fig 3). A $x^{2}$ statistic was used to test for homogeneity among classes of deer (Sauer and Williams 1989) based on sex, age and study area. A z-test (Heisey and Fuller 1985, Nelson and Mech 1986) was used to make individual comparisons. 


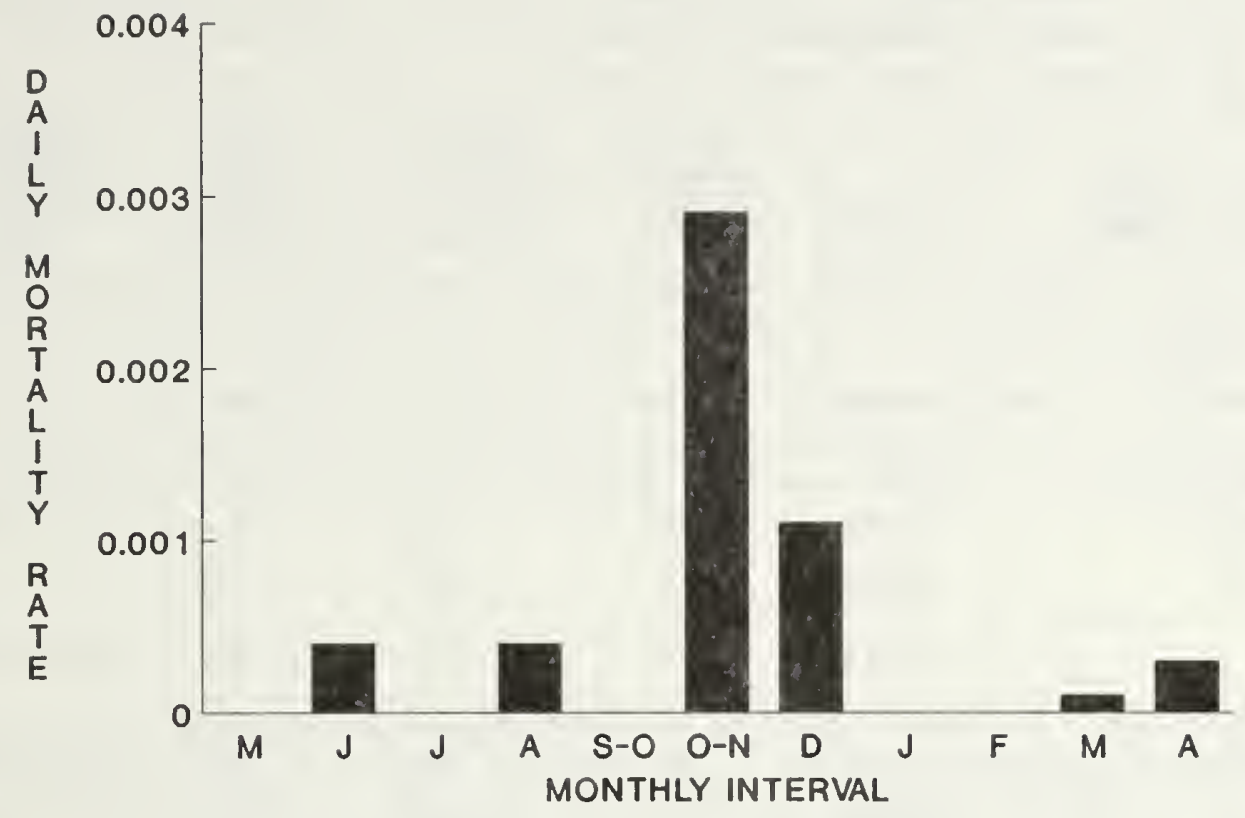

Figure 3. Daily mortality rates during monthly intervals for all deer ( $\geq 1$ year old) pooled for all sex and age cohorts. s-o includes the period of archery hunting ( 1 Sep-15 Oct), and $0-\mathrm{N}$ includes the 5-wk firearm hunt (16 Oct-30 Nov).

\section{RESULTS AND DI8CU8SION}

\section{Trap Efficiency}

From 3 January through 23 February 1991, a total of 181 white-tailed deer were captured over 331 trap-nights, including all recaptures and mortalities, for an overall trap efficiency of 0.55 deer caught/trap-night. Trap efficiency in 1991 was higher $(P<0.01)$ than during the 2 previous years (Table 1$)$. That at MDWR nearly doubled from 1990 and was higher $(P<0.01)$ than that at BTWR. This perhaps was attributable to less time spent trapping on MDWR. Most trapping on BTWR occurred in areas also trapped in previous years, and thus, some deer probably were conditioned to avoid traps. Two deer ( $<2 \%$ of all captures) died at the trapsite during winter 1991. All resulted directly from trap-related injuries. 
Table 1. Efficiency of Clover traps for capturing white-tailed deer on 2 winter ranges, 1988-91.

\begin{tabular}{|c|c|c|c|c|c|}
\hline $\begin{array}{l}\text { Month and } \\
\text { location }\end{array}$ & Year & $\begin{array}{l}\text { Total } \\
\text { trap } \\
\text { nights }\end{array}$ & $\begin{array}{l}\text { Total } \\
\text { deer } \\
\text { captured }\end{array}$ & $\begin{array}{l}\text { Total } \\
\text { deer } \\
\text { marked }\end{array}$ & $\begin{array}{l}\text { Total } \\
\text { captures/ } \\
\text { trap night }\end{array}$ \\
\hline \multicolumn{6}{|l|}{ December } \\
\hline BTWR & 1988 & 100 & 41 & 30 & 0.41 \\
\hline \multicolumn{6}{|l|}{ January } \\
\hline \multirow[t]{3}{*}{ BTWR } & 1989 & 152 & 53 & 41 & 0.35 \\
\hline & 1990 & 193 & 66 & 55 & 0.34 \\
\hline & 1991 & 105 & 51 & 43 & 0.49 \\
\hline \multirow[t]{3}{*}{ MDWR } & 1989 & 70 & 27 & 24 & 0.39 \\
\hline & 1990 & 45 & 20 & 17 & 0.44 \\
\hline & 1991 & 72 & 60 & 49 & 0.83 \\
\hline \multicolumn{6}{|l|}{ February } \\
\hline \multirow[t]{3}{*}{ BTWR } & 1989 & 129 & 65 & 52 & 0.50 \\
\hline & 1990 & 162 & 54 & 42 & 0.33 \\
\hline & 1991 & 154 & 70 & 47 & 0.45 \\
\hline \multirow[t]{2}{*}{ MDWR } & 1989 & 42 & 22 & 20 & 0.52 \\
\hline & 1990 & 44 & 32 & 28 & 0.73 \\
\hline \multicolumn{6}{|l|}{ March } \\
\hline BTWR & 1989 & 42 & 19 & 13 & 0.45 \\
\hline \multirow[t]{3}{*}{ Total } & 1989 & 535 & 227 & 175 & 0.42 \\
\hline & 1990 & 429 & 172 & 142 & 0.40 \\
\hline & 1991 & 331 & 181 & 139 & 0.55 \\
\hline
\end{tabular}

a Bowser-Tally Lakes winter range (BTWR); Murphy-Dickey Lakes winter range (MDWR). 
Since the project was initiated, 541 white-tailed deer have been marked and 136 have been radio-collared. During the year ending 31 May 1991, 10 whitetails were captured on summer range during June-August 1990, and 139 deer were captured on winter ranges during January-February 1991. Twelve deer initially captured and marked during previous winters were recaptured during winter 1991. The radio collar was replaced on an adult female (88020) recaptured on the Bowser-Tally winter range (BTWR) and on an adult female (89201) on the Murphy-Dickey Lake winter range (MDWR). Neckbands on 4 other deer ( 2 each on BTWR and MDWR) were replaced with radio collars. One of these individuals included an adult female initially captured and neckbanded on BTWR in 1990 and recaptured at MDWR in 1991. During winter 1991, 90 new deer were marked on BTWR, and 49 were marked on MDWR. Effort during 1991 involved roughly maintaining 60-70 radiocollared deer on BTWR while increasing the sample on MDWR from 16 to 30 individuals.

\section{Camera surveys}

The three camera surveys during winter 1990-91 resulted in 1,202 exposures at 31 sites (Table 2). Of all exposures, 845 (70\%) were of wildlife; 810 (67\%) were of white-tailed deer from which 722 individual deer-visits were identified. Other wildlife identified in photographs included mule deer (O. hemionus), coyotes (Canis latrans) and cougars (Felis concolor).

System check exposures and those from unknown causes (Table 2) accounted for 9 and 21\%, respectively, of all exposures. Most exposures caused by unknown variables presumably resulted from animals moving out of the field of view during the 2-3 second lapse between detection by the PIR sensor and shutter release. Some may have been triggered by environmental conditions including precipitation, wind, and a rapid change in direct sunlight (Mace et al. 1990), although effects of these conditions appeared minimal during winter. Efficiency of the system for photographing deer on winter ranges was similar to that reported for the previous year (Dusek and Mace 1991). A decreased proportion of deer photographed at night from early to late winter (Table 2), similarly observed in 1989-90, suggested a transition from daily activity rhythms balanced between diurnal and nocturnal periods in early winter to a strongly diurnal rhythm by late winter.

Though total deer-visits (Table 2) do not necessarily equal total individuals photographed during an individual survey, a low frequency of visitation by individually marked deer suggested most deer were photographed only once during a survey. Only one of 20 collared deer photographed in 1990-91 made a second visit to the same camera site within a 2-week period. Deer appeared to have responded to camera noise, flash, etc. by using alternate 
Table 2. Summary of remote camera surveys at Bowser and Murphy-Dickey Lakes winter ranges during winter 1990-91.

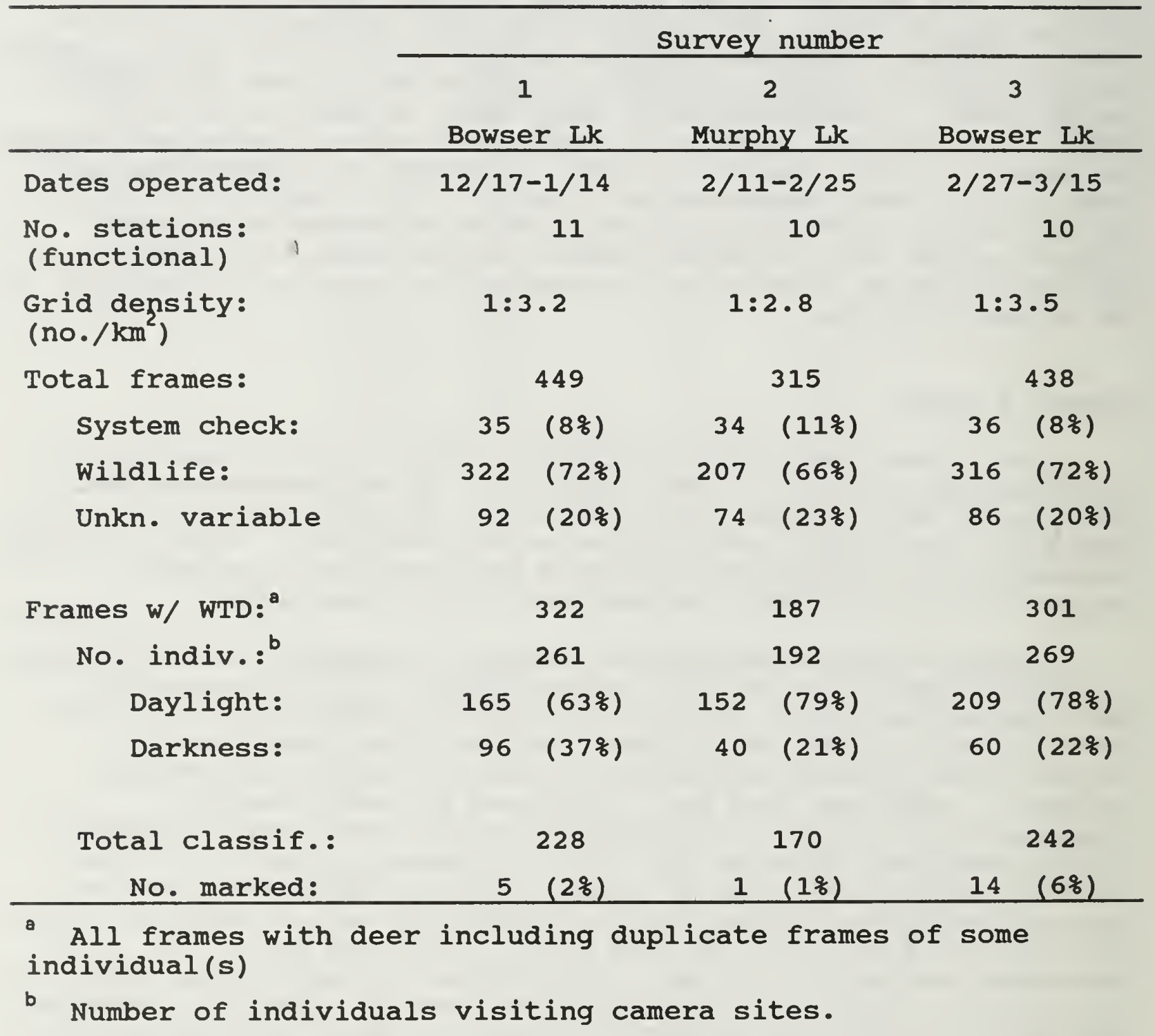

trails during subsequent daily travel through the camera site. The number of deer visiting camera sites per day decreased with time from the beginning of a session (Fig. 4). Baiting sites with an aromatic attractant, in this case anise oil, apparently did not alter the downward trend in daily rate of deer-visits (Fig. 5). 


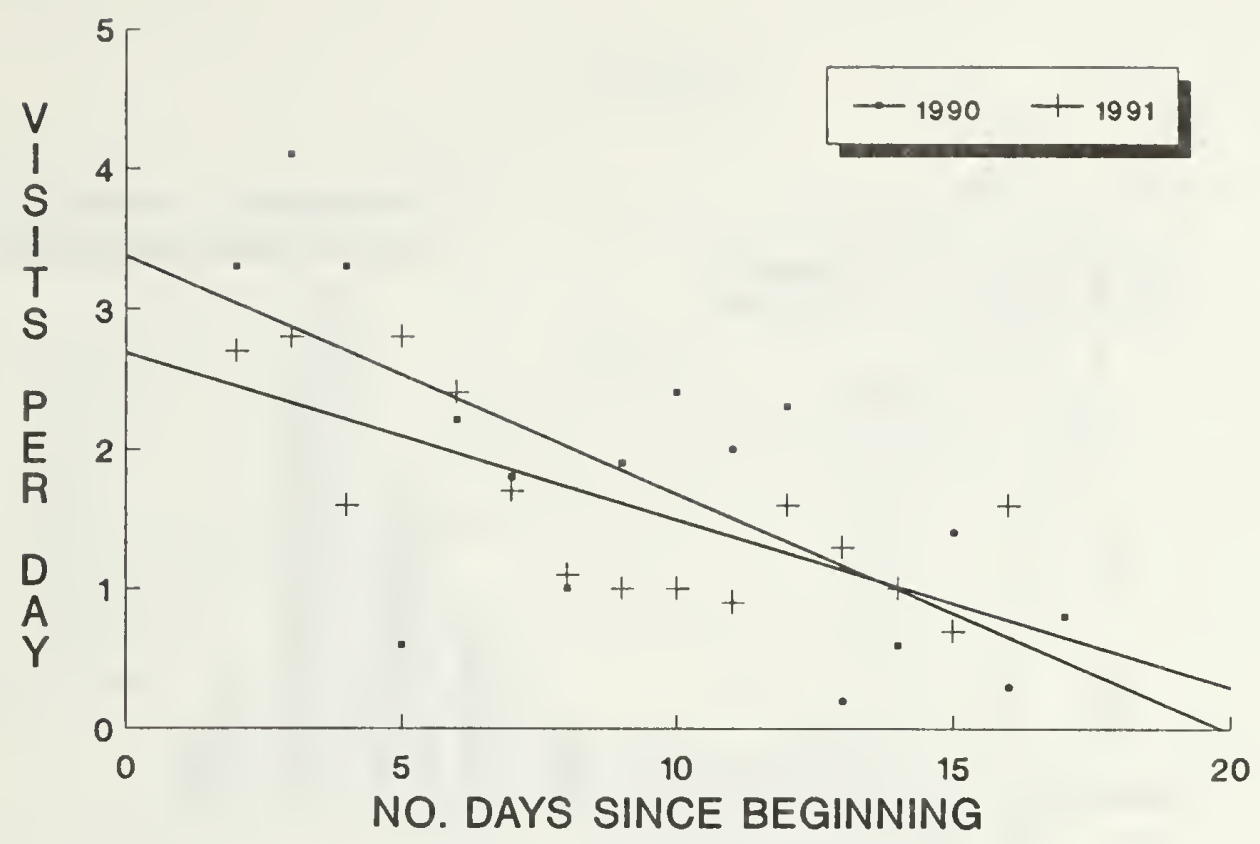

Figure 4. Trend in deer-visits per day during late winter camera surveys on Bowser-Tally Lakes winter range, 1990-1991.

Population Characteristics

Herd Composition.--Composition of the population on the BTWR during winter and in the Tally Lake District during early spring appears in Table 3. Composition of harvested and trapped samples of deer appear in Figures 6 and 7 . The proportion of fawns in late winter-spring populations during 1989-91, 42\%, 40\%, and 36\%, respectively, did not differ between years $(P=0.21)$. The proportion of fawns in trap samples on BTWR during 1989-91, (45, 42 , and $43 \%$, respectively) did not differ from combined yearly samples (camera and other) during any year $(P>0.20)$.

Recruitment during late winter-early spring 1989-91 (39\% for all years combined) was higher $(P<0.001)$ than that reported during 1982-83 (25\%) by Mundinger and Riley (1983) based on respective samples $>1200$ classified deer. There was little apparent change in herd composition with respect to fawns and adults from early to late winter during either 1990 or 1991 (Table 3). Young: adult ratios determined from remote photography were comparable to 


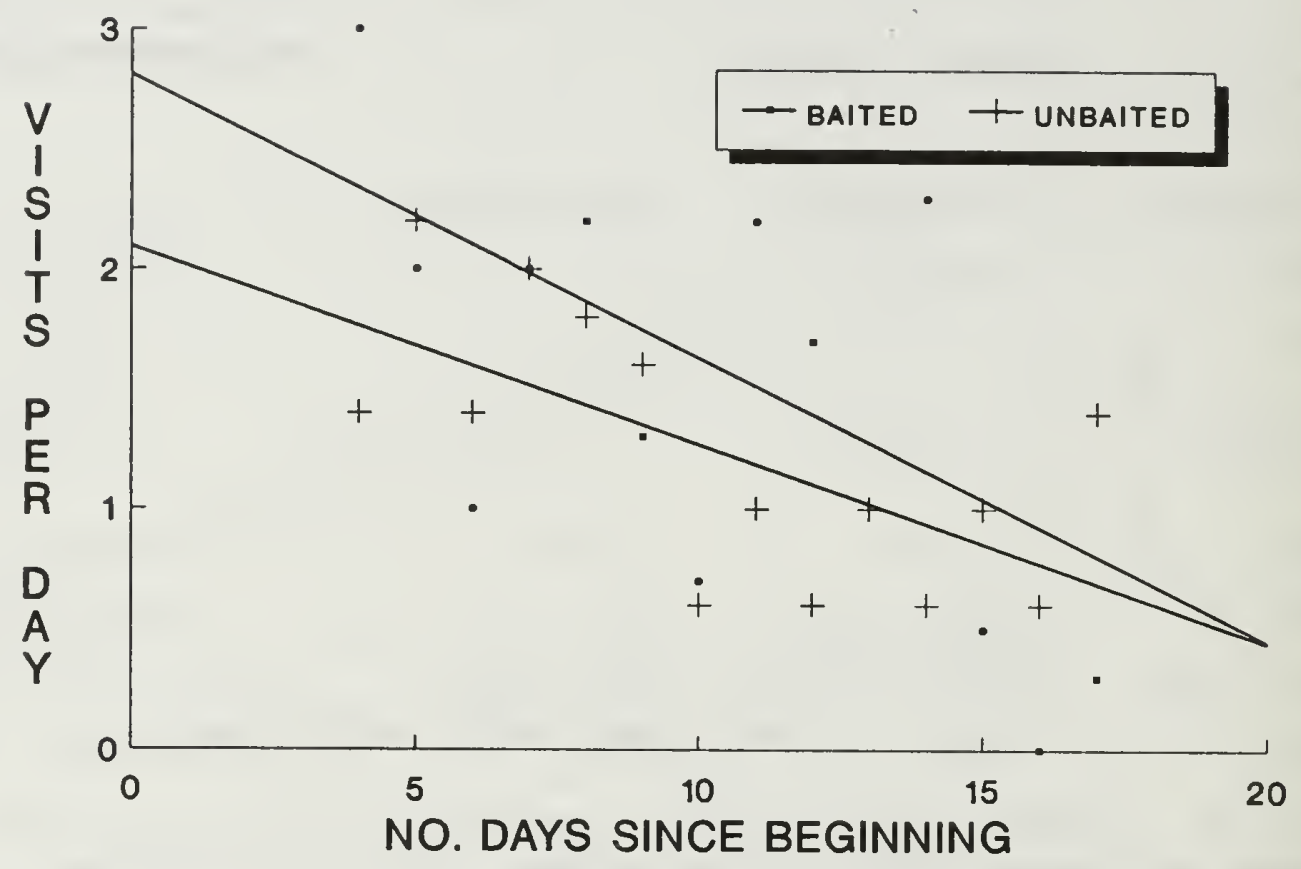

Figure 5. Trend in deer-visits per day at baited and unbaited sites during the early winter camera survey on Bowser-Tally Lakes winter range in 1990 .

those obtained by direct observation during late winter, 1990 and 1991 .

During late winter of 1990 and 1991,173 and 170 whitetailed deer were classified from camera surveys at MDWR. Of these, $32 \%$ and $41 \%$ were fawns during the respective years. Based on classifications exclusively from camera surveys at MDWR and BTWR, there were no spatial or temporal differences $(P=0.31)$ in the proportion of fawns within or between years on these winter ranges.

Sex ratio of fawns on both winter ranges was assumed equally represented by males and females. Although males slightly outnumbered females among fawns examined at hunter check stations (52\%, $n=44$ ) and among fawns trapped during winter (51\%, $n=$ 211), sex ratios did not depart from an expected ratio of $1: 1$ ( $P$ $\geq 0.50)$. 


\section{MALES}

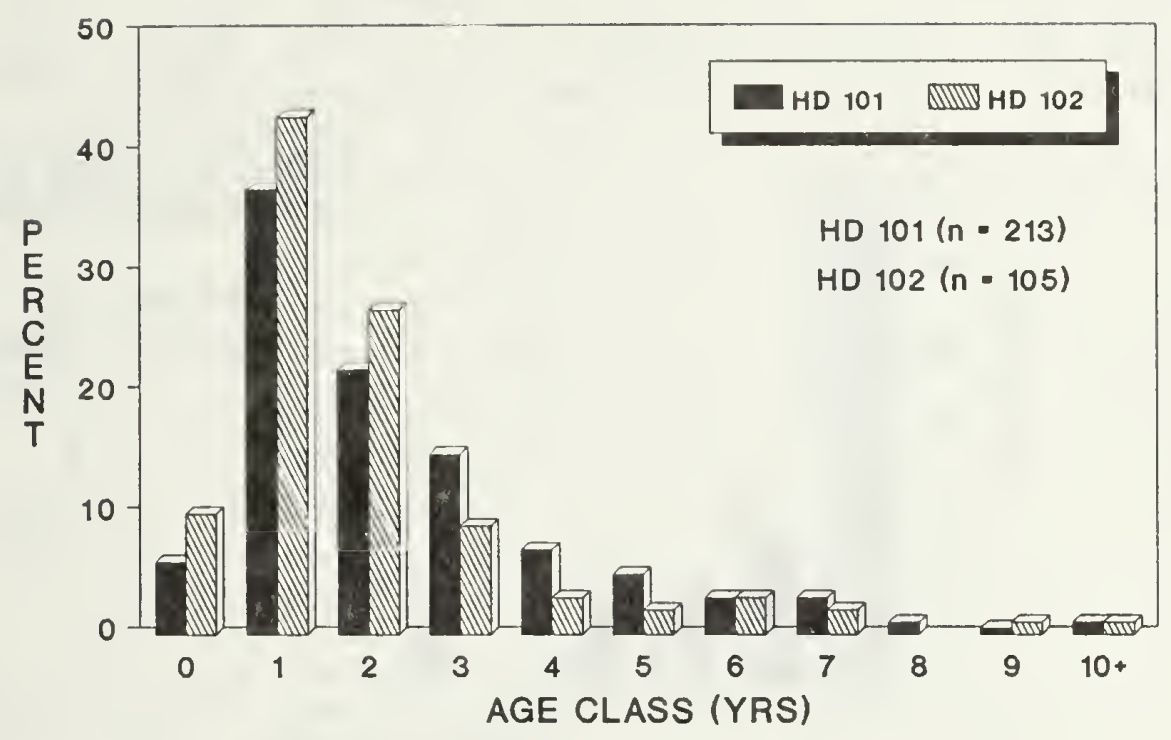

FEMALES

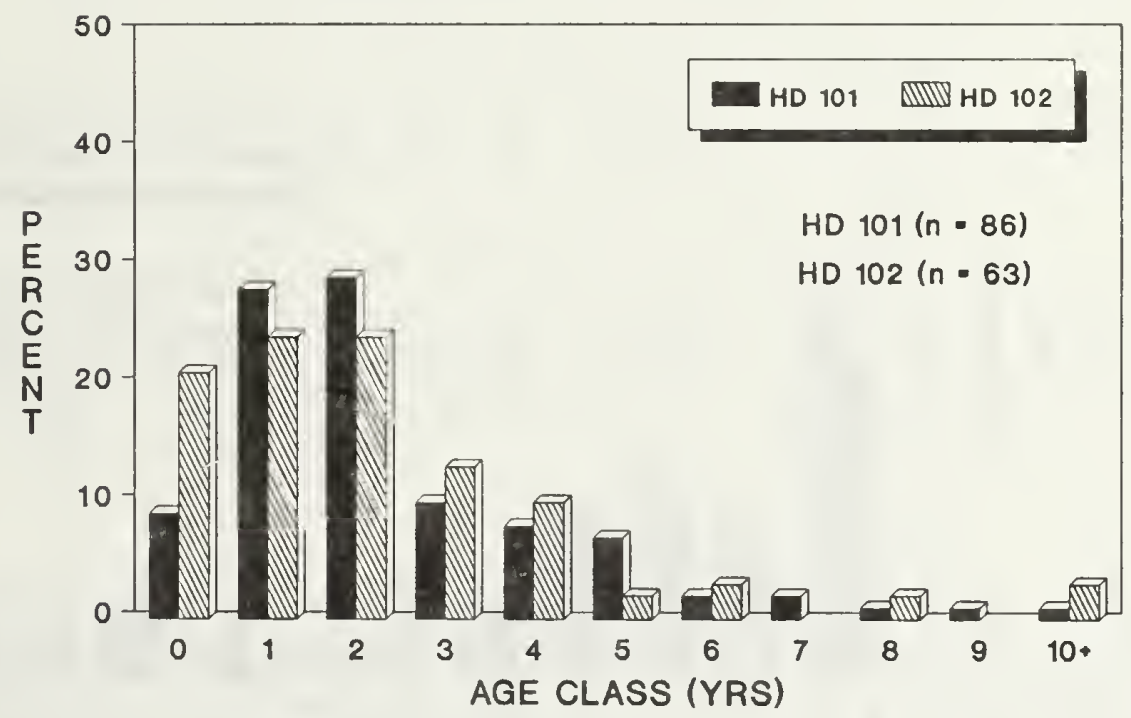

Figure 6. Age composition of the whitetail harvest pooled by sex in hunting districts 101 and 102, 1988-90. 


\section{MALES}

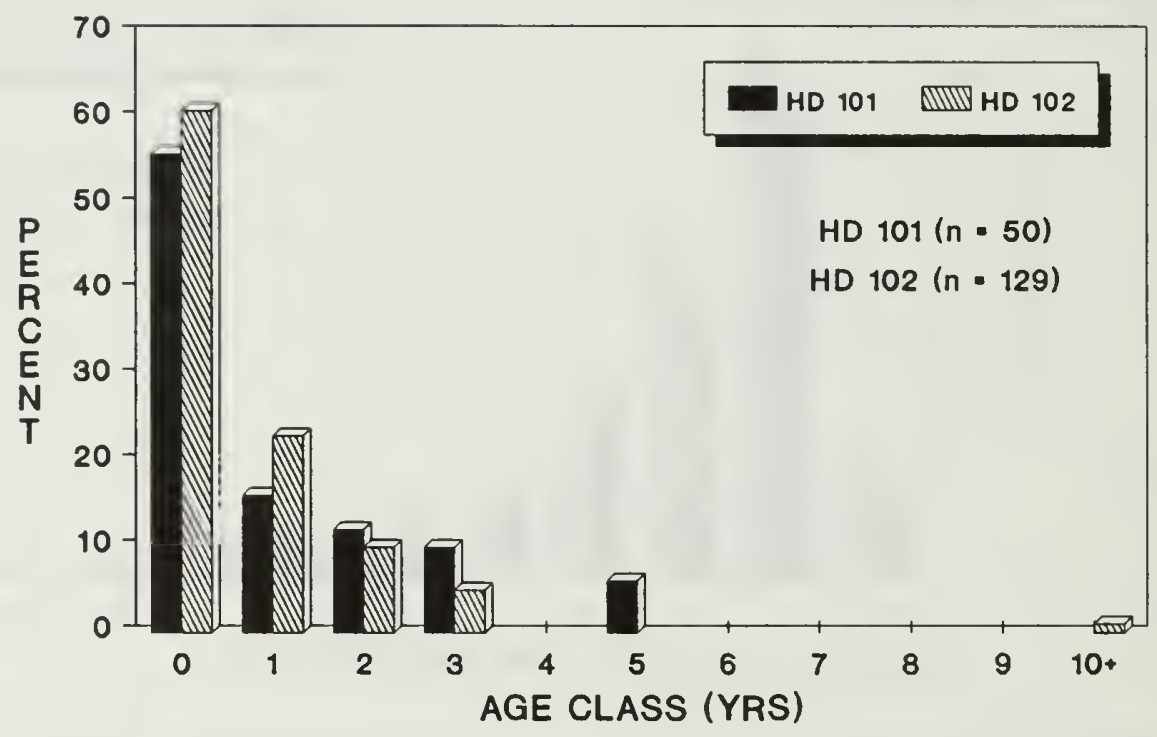

FEMALES

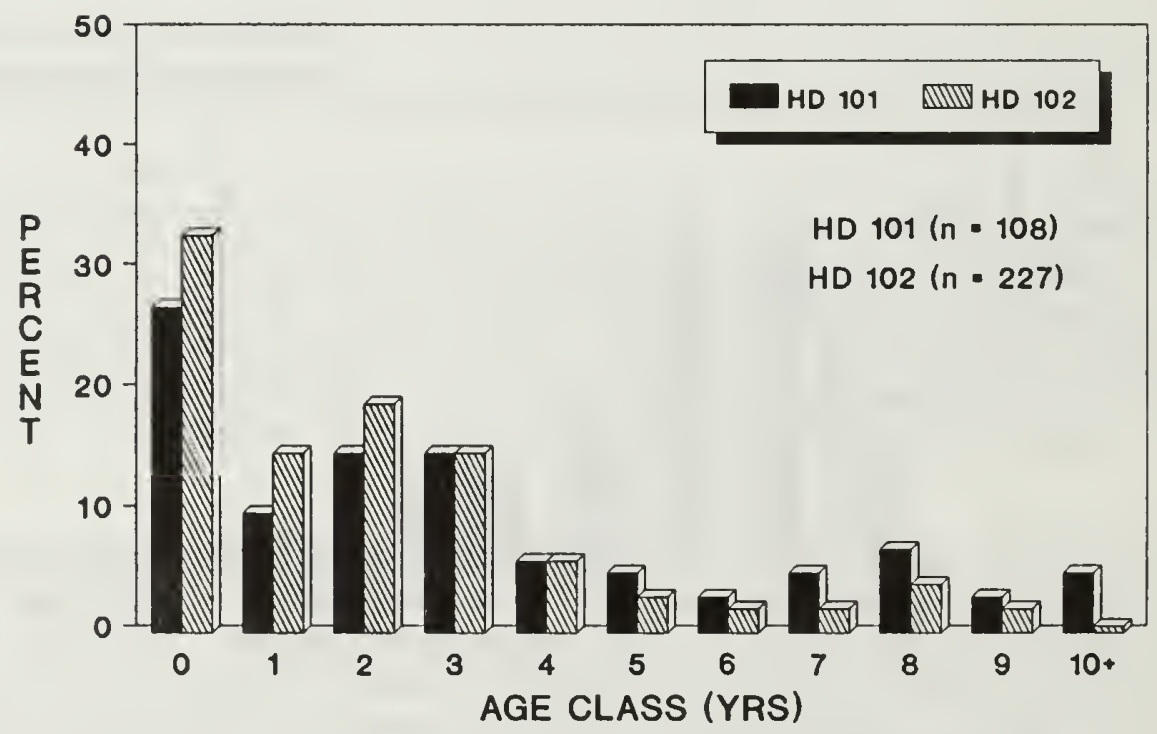

Figure 7. Age composition of captured whitetails pooled by sex in hunting districts 101 and 102, 1988-91. 


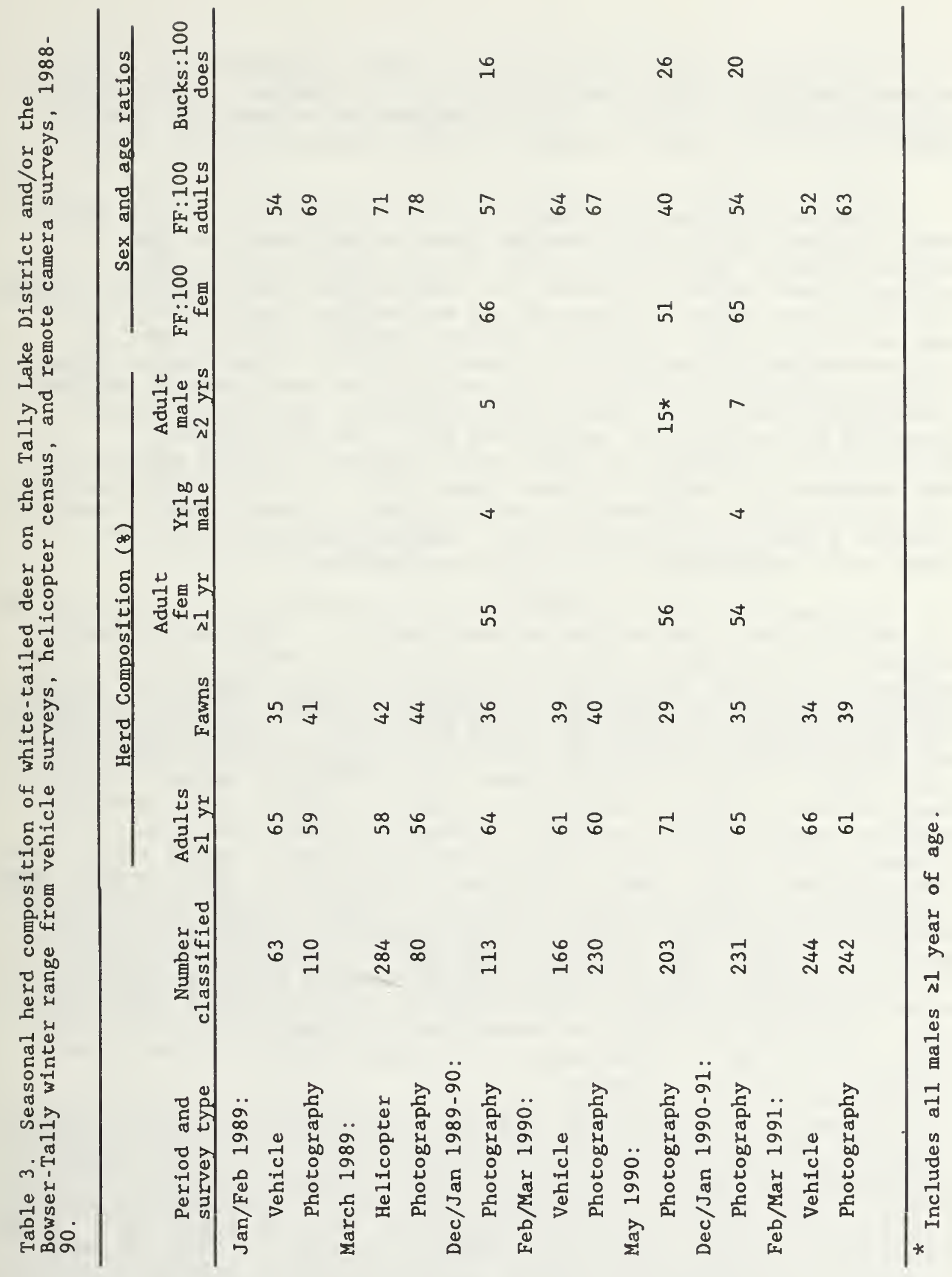


A sample of 206 deer of ages $\geq 1$ year classified in and around the Tally Lake District during July-August 1990 yielded a buck: doe ratio of 36:100. This compared to a ratio of $20: 100$ resulting from a camera survey on BTWR during December 1990.

Population Size and Trend.--A minimum sample of 154 marked deer occurred within the Bowser Lake survey area in late February-early March 1991. The sample included all radiocollared deer using the area, all neckbanded deer captured within the area just prior to the survey excluding known mortalities, and neckbanded deer captured during previous years known by reobservation or recapture to have survived. The remote camera survey suggested that $6 \%$ of the population were marked, whereas classification of 141 deer from snowmobile surveys following trapping in late winter suggested that $13 \%$ were marked. Mortality was assumed minimal from December through mid-March, and movement by radio-collared deer into or out of the area also was minimal and confined to the periphery. Monte carlo results yielded a MLE of 2,815 (Fig. 8). Estimates were based on sampling a maximum of $11 \%$ of the population.

The pellet group survey yielded an estimate of 3,511 deer on the BTWR survey area during winter 1990-91. This was slightly higher than estimates for the previous 2 winters (Fig. 9). Two variables must be estimated with reasonable accuracy for pellet group counts to reflect actual numbers of deer. Number of days that deer occupy the winter range (125 days in winter 1990-91) was determined from average dates of entry onto and departure from BTWR by radio-collared deer, i.e., average number of days that autumn migrants occupied the winter range. The second and perhaps most critical variable is daily defecation rate. The commonly used rate (12.7 groups/day/individual, Davis 1982), and one used here, was less than rates reported for free-ranging deer (Rogers 1987, Sawyer et al. 1990). Because of the likelihood of substantial regional variation in defecation rates and no comparative data for white-tailed deer in the northern Rocky Mountain region, pellet group counts provide only an index of animal abundance on the winter range. It is assumed that the rate, although probably not accurate, was relatively constant from year to year. Precision of current sampling effort (650 plots $)$ is $\pm 11 \%(\alpha=0.05)$.

Numbers of deer using BTWR as determined from pellet group counts were substantially higher than those from mark-recapture techniques and probably overestimated numbers of deer on the survey area. However, estimates from both techniques appear to reflect a similar trend in abundance of deer on BTWR (Figs. 8 and 9) despite slightly differing patterns of use of BTWR between winters. For example, some radio-collared deer marked on BTWR in 1988-89 did not use the winter range in 1989-90 but did use it 


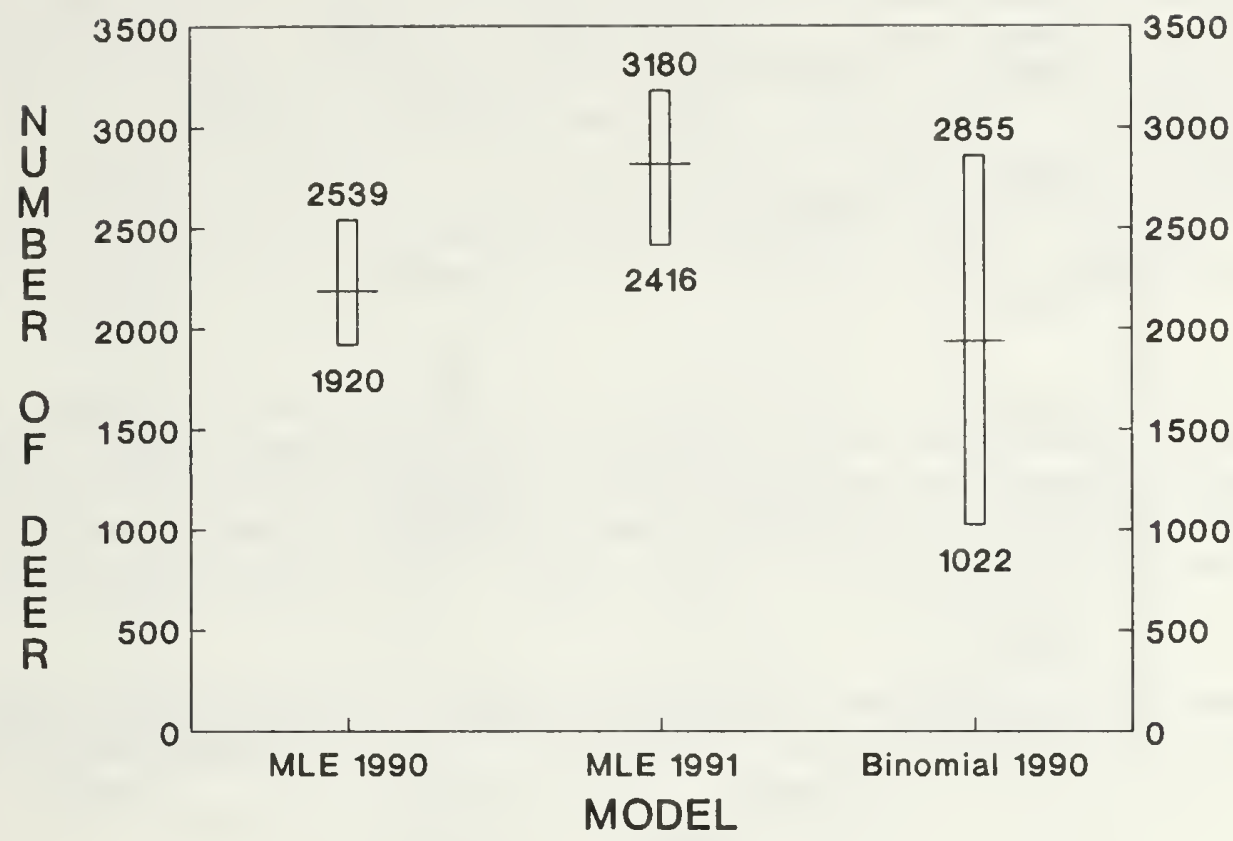

Figure 8. Maximum likelihood estimates (MLE) for the Bower-Tally Lakes winter range (BTWR) with 95\% likelihood intervals, 1990-91, and a point estimate and $95 \%$ confidence interval from Bailey's Binomial, 1990, for comparison.

again in 1990-91. Additionally, fall migration was staggered through late January 1990, whereas all radio-collared deer were on the winter range by late December 1990. Thus, minor differences between years also may reflect these events and several years of data wili be necessary to determine subtle changes in population size.

Condition Parameters.--Whole weights determined from heart girth during January-February 1989-91 increased with age through at least 4 years among both sexes of deer and sex, age, and year accounted for $93 \%$ of the variation in weight during that period (Dusek and Morgan 1990). Whole weights of deer harvested during October-November were estimated from dressed weights (Table 4) using a dressing index, or dressed weight expressed a proportion of whole weight, from 30 deer collected for study $(\bar{x}=0.70)$. Whole and dressed weights of deer during other periods of the 


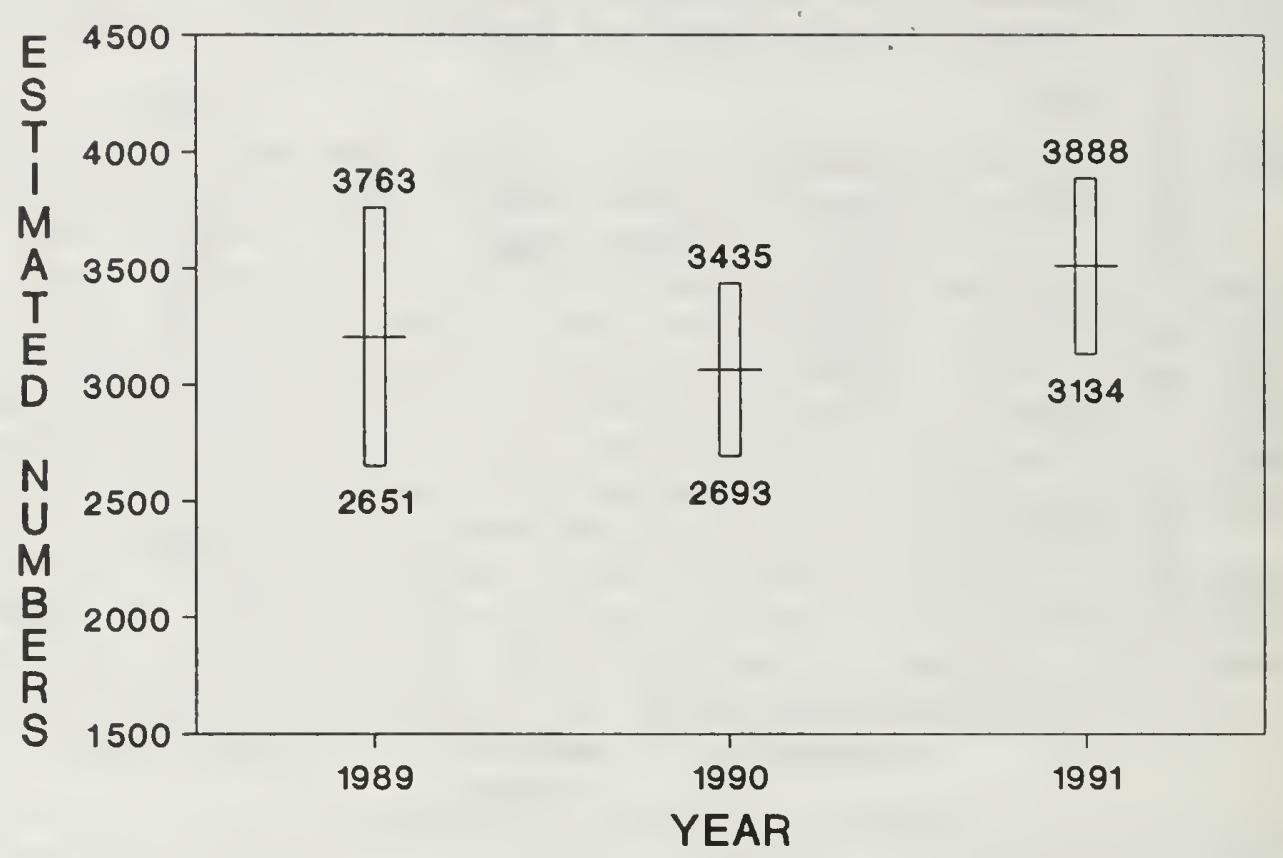

Figure 9. Estimates of numbers of deer using the Bowser-Tally Lakes winter range (BTWR), 1989-91, from pellet group counts with 95\% confidence intervals.

Table 4. Average field-dressed weights $(\mathrm{kg})$ of 151 white-tailed deer examined at check stations from hunting districts 101, 102, and 110, 1989-90.

\begin{tabular}{|c|c|c|c|c|}
\hline \multirow[b]{2}{*}{ Age } & \multicolumn{2}{|c|}{$\underline{98}$} & \multicolumn{2}{|c|}{$\underline{00}$} \\
\hline & $\underline{\mathrm{n}}$ & $\underline{\underline{x}}$ & $\underline{\mathrm{n}}$ & $\underline{\underline{x}}$ \\
\hline 0 & 7 & 24.3 & 6 & 29.6 \\
\hline 1 & 18 & 39.0 & 29 & 48.1 \\
\hline 2 & 16 & 44.9 & 27 & 59.2 \\
\hline 3 & 10 & 45.3 & 11 & 67.7 \\
\hline 4 & 5 & 44.9 & 6 & 77.9 \\
\hline 5 & 2 & 51.1 & 4 & 87.8 \\
\hline 6 & 1 & 38.6 & 4 & 80.9 \\
\hline 7 & 1 & 45.4 & 1 & 88.5 \\
\hline$\geq 8$ & 1 & 46.3 & 2 & 78.8 \\
\hline
\end{tabular}


year were determined by use of a spring scale. Estimated whole weights of deer during 5 periods throughout the year appear in Table 5. Deer apparently experienced weight loss between late autumn and January, a period that included the breeding season, onset of cold winter weather, and migration from summer to winter ranges. During January-February, weight loss may have been somewhat more gradual. Such an initial, rapid loss of weight, followed by a leveling off or more gradual weight loss through winter, also was consistent with physiological and behavioral adaptation to winter in northern environments where forage resources occur in limited abundance and/or quality (Peek et al. 1990).

Mean basal diameter and mean length of the main antler beam, and maximum spread among males $\geq 1$ year of age increased with age (Dusek 1989). Average main beam length appeared somewhat more variable between years (1988-90) among yearling and 2-year-old males than among older males (Fig. 10). For this reason and the

Table 5. Estimated whole weights $(\mathrm{kg})$ by season, sex, and age of white-tailed deer in the Salish Mountains study area, 1988-91.

Season

\begin{tabular}{|c|c|c|c|c|c|c|c|c|c|c|c|}
\hline \multirow[b]{2}{*}{ Sex } & \multirow[b]{2}{*}{ Age } & \multicolumn{2}{|c|}{ Jun-Jul } & \multicolumn{2}{|c|}{ Aug-Sep } & \multicolumn{2}{|c|}{ Oct-Nov } & \multicolumn{2}{|c|}{$\underline{J a n-F e b}$} & \multicolumn{2}{|c|}{ Apr-May } \\
\hline & & $\underline{n}$ & $\underline{\underline{x}}$ & $\underline{n}$ & $\underline{\bar{x}}$ & $\underline{n}$ & $\underline{\bar{x}}$ & $\underline{n}$ & $\underline{x}$ & $\underline{n}$ & $\underline{x}$ \\
\hline \multirow[t]{5}{*}{89} & 0 & & & & & 7 & 34.6 & 87 & 30.6 & 1 & 31.8 \\
\hline & 1 & 3 & 40.7 & 1 & 43.1 & 18 & 55.6 & 47 & 47.9 & 1 & 45.9 \\
\hline & 2 & 2 & 46.5 & 2 & 55.2 & 16 & 64.0 & 55 & 54.3 & 2 & 50.8 \\
\hline & 3 & 1 & 51.3 & 1 & 54.5 & 10 & 64.5 & 49 & 50.0 & & \\
\hline & $\geq 4$ & 1 & 52.2 & 2 & 58.6 & 10 & 65.1 & 80 & 57.0 & 3 & 58.9 \\
\hline \multirow[t]{5}{*}{ की } & 0 & & & 1 & 22.2 & 6 & 42.1 & 96 & 31.6 & & \\
\hline & 1 & 1 & 43.6 & 2 & 56.5 & 29 & 68.5 & 41 & 51.5 & 2 & 50.4 \\
\hline & 2 & 1 & 71.3 & & & 27 & 84.3 & 16 & 55.1 & & \\
\hline & 3 & & & & & 11 & 96.4 & 11 & 66.4 & & \\
\hline & $\geq 4$ & & & & & 17 & 116.3 & 4 & 68.7 & & \\
\hline
\end{tabular}




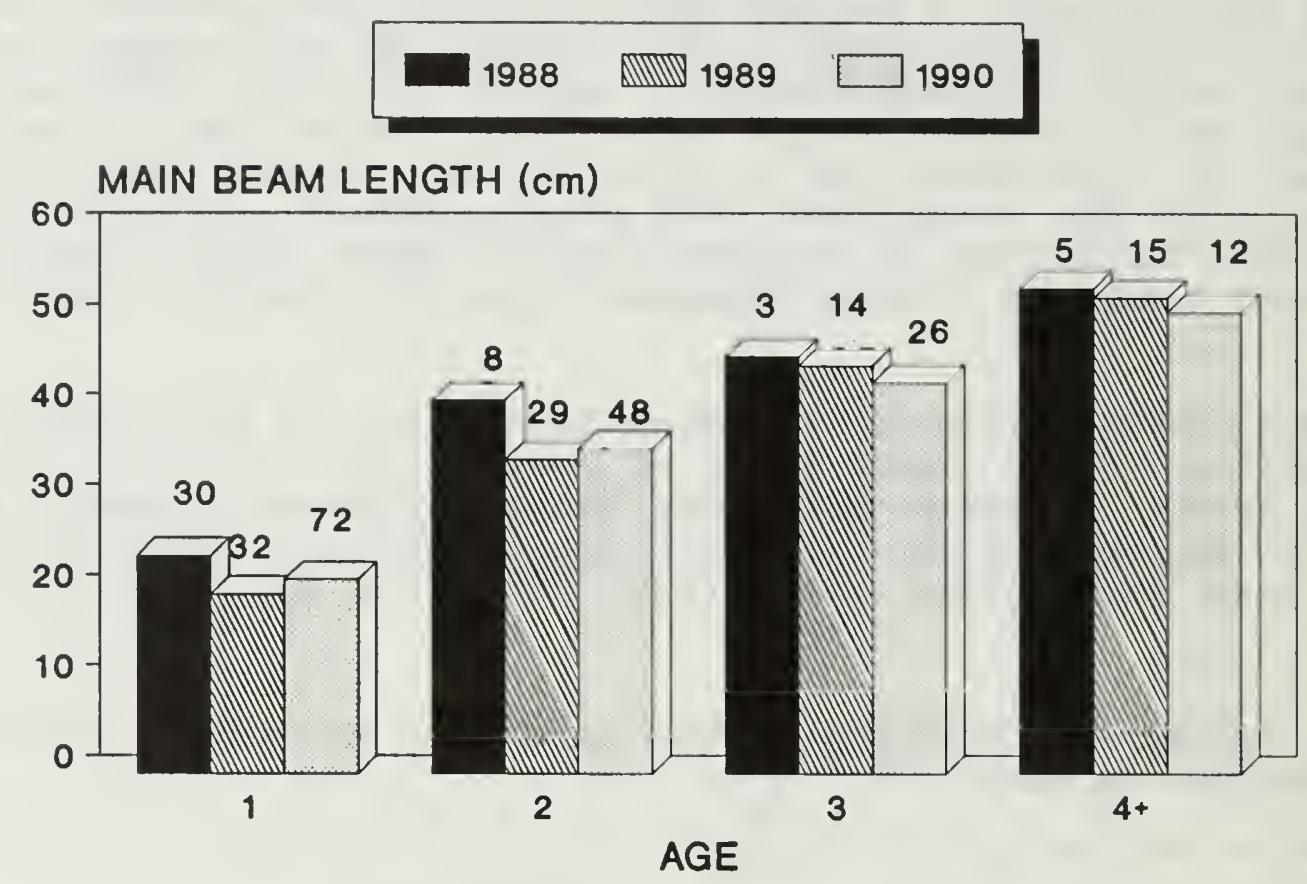

Figure 10. Main antler beam length $(\mathrm{cm})$ by age and year for males $\geq 1$ year of age from hunting districts 101, 102, and 110, 1988-90.

fact that they were numerically better represented among all age classes examined at check stations, beam basal diameter, diastemal length, and dressed carcass weight of yearling males were examined by hunting district (Table 6). Yearlings had experienced only 1 winter, thus minimizing cumulative effects of environmental conditions on growth and condition over several years (Swenson and Stewart 1982). No real differences were apparent in the 3 variables between hunting districts or years.

Reproduction.--Radioimmunoassay for pregnancy-specific protein B (PSPB) in serum (Wood et al. 1986) from 316 female white-tailed deer during 1988-91 indicated that yearlings were essentially the youngest breeding age class (Table 7). Only 3 $(4 \%)$ of 84 fawns had bred, whereas serum assay indicated that 44 (94\%) of 47 yearlings were pregnant. Pregnancy rate appeared to increase through 4 years of age, but differences between age classes older than fawns were not significant $(P=0.31)$. Of 54 and 512 - and 3-year-old females, 50 (93\%) and 49 (96\%), respectively, were pregnant. 
Table 6. Main antler beam diameter $(\mathrm{cm})$, diastemal length (mm), and dressed carcass weight $(\mathrm{kg})$ of yearling male white-tailed deer examined at check stations from hunting districts 101 and $102,1988-90$.

\begin{tabular}{|c|c|c|c|c|c|c|c|c|c|c|}
\hline \multirow[b]{2}{*}{ Year } & \multirow[b]{2}{*}{ HD } & \multicolumn{3}{|c|}{ Beam diam. } & \multicolumn{3}{|c|}{ Diastema } & \multicolumn{3}{|c|}{ Weight } \\
\hline & & $\underline{\mathrm{n}}$ & $\underline{\bar{x}}$ & SE & $\underline{\mathrm{n}}$ & $\underline{x}$ & SE & $\underline{n}$ & $\underline{\bar{x}}$ & SE \\
\hline \multirow[t]{2}{*}{1988} & 101 & 10 & 1.8 & 0.1 & 14 & 72.4 & 0.9 & & & \\
\hline & 102 & 14 & 2.0 & 0.1 & 14 & 72.4 & 0.6 & & & \\
\hline \multirow[t]{2}{*}{1989} & 101 & 17 & 1.7 & 0.1 & 18 & 69.6 & 0.9 & 6 & 49.2 & 1.0 \\
\hline & 102 & 10 & 1.8 & 0.1 & 9 & 68.9 & 1.2 & 4 & 48.8 & 2.0 \\
\hline \multirow[t]{2}{*}{1990} & 101 & 46 & 1.8 & 0.0 & 45 & 70.6 & 0.6 & 7 & 49.6 & 1.6 \\
\hline & 102 & 19 & 1.7 & 0.1 & 19 & 70.0 & 0.9 & 9 & 46.7 & 1.6 \\
\hline
\end{tabular}

Table 7. Age specific pregnancy rates of white-tailed deer from serum assay among 316 captured females, 1988-91.a

Age

\begin{tabular}{|c|c|c|c|}
\hline & Fawns & Yearlings & Adults \\
\hline Year bred & \% preg. & \% preg. & \% preg. \\
\hline
\end{tabular}

$\begin{array}{rrrrrrr}1987 & 11 & 0 & 3 & 100 & 13 & 92 \\ 1988 & 27 & 7 & 14 & 100 & 60 & 95 \\ 1989 & 23 & 4 & 12 & 83 & 49 & 96 \\ 1990 & 23 & 0 & 18 & 94 & 63 & 98\end{array}$

$\begin{array}{llllllll}\text { All years } & 84 & 4 & 47 & 94 & 185 & 96\end{array}$

a serum samples were taken during late December through early March on the Bowser-Tally and Murphy-Dickey Lakes winter ranges. 
Yearly variation in pregnancy rates (93-98\%) for combined samples of females $\geq 1$ year of age was not significant $(P=0.66)$. Pregnancy rates at BTWR (96\%) and MDWR (95\%) for all years combined were not different $(P=0.62)$ based on samples from the respective areas of 156 and 76 females.

Fifteen females ( 3 fawns, $12 \geq 1 \mathrm{yr}$ ) were necropsied to determine reproductive status during 1989-91. Most were collected for the purpose of study in the Tally Lake District. None of the fawns were pregnant, but among females of ages $\geq 1$ year, all were pregnant producing a total of 21 fetuses (175:100 producing females; 140:100 total females). Two yearling females in the sample each carried a single fetus, whereas 9 of 10 females of ages $\geq 2$ years carried twin fetuses. Of 16 fetuses for which sex was determined, 9 and 7 were males and females, respectively.

only 26 (17\%) of 151 yearling and older females classified in and around the Tally Lake District during July-August 1990 were accompanied by fawns. Nineteen does were accompanied by a single fawn, and 7 had twins at-heel resulting in a ratio of fawns:producing female of 127:100. This compared to 139:100 producing females in 1989 (Dusek and Morgan 1990). Although annual reproductive success cannot be directly estimated from summer classification surveys, production among reproductively successful does probably can be used as an index of early reproductive success.

Reproductive success also was determined from reobservation of 60 individually marked females ( $\geq 1 \mathrm{yr}$ ) associated with BTWR or MDWR during the combined years of 1989 and 1990 (Table 8). These observations were made over the period of August-May and should represent a reasonable estimate of the proportion of females rearing fawns to an age of weaning (about 4 mos). Thirty-seven (62\%) were accompanied by fawn(s) that included 1 of 6 yearling females. Among adult females ( $\geq 2$ yrs) with fawns $(n=36), 11$ had twins at-heel, and 25 were accompanied by a single fawn. Reproductive success increased with age at least through 7 years (Table 8 ). Of females $\geq 8$ years of age, 7 of 8 reared fawns but produced fewer fawns: female than those of ages 4-7 years. The sample, irrespective of age class, yielded fawn:female ratios of 130:100 producing females and 80:100 total females. The latter ratio was somewhat higher than those observed on BTWR during December (Table 3 ). The ratio of fawns:producing female compared favorably with that from samples of classified deer (both marked and unmarked) during July-August. These data in addition to fetal rates suggested some early post-partum loss of fawns. 
Table 8. Age specific recruitment of fawns from 60 individually marked does associated with Bowser-Tally and Murphy-Dickey Lakes winter ranges, 1989-90.

\begin{tabular}{|c|c|c|c|c|}
\hline Age & No. QQ & $\begin{array}{c}\text { No. } ९ Q \\
\text { successful }\end{array}$ & $\begin{array}{c}\text { Fawns: } 100 \\
\text { Prod. } \$ Q\end{array}$ & $\begin{array}{c}\text { Fawns: } 100 \\
\text { total } 99\end{array}$ \\
\hline 1 & 6 & 1 & 100 & 17 \\
\hline 2 & 10 & 5 & 120 & 60 \\
\hline 3 & 9 & 7 & 100 & 78 \\
\hline 4 & 12 & 8 & 138 & 92 \\
\hline $5-7$ & 15 & 9 & 156 & 93 \\
\hline$\geq 8$ & 8 & 7 & 129 & 113 \\
\hline
\end{tabular}

Survival/Mortality.--Annual survival (Fig. 11) differed with respect to sex and age but not between study areas. Chi-square tests indicated differences among all classes $(P<0.01)$ and among all classes of females $\geq 1$ year of age associated with BTWR. A lack of significant difference among all classes of females associated with MDWR $(P=0.76)$ probably reflected a comparatively small sample of radioed deer there. For females associated with BTWR/Tally Lake District, annual probabilities of survival among yearling (0.93) and 2-7 year-old females (0.90) did not differ $(P=0.31)$, but survivorship of both classes were higher $(P<0.01)$ than that of females $\geq 8$ years of age $(0.85)$. Survivorship was not determined for fawns and yearling males in both study areas or for adult males at MDWR because radioed individuals in these groups were not available for study throughout the mortality year. Thus, samples of radio-collared deer from both areas were combined to illustrate overall trends in survival and cause-specific mortality (Table 9).

Yearling and older females from both study areas combined exhibited higher survivability than adult males ( $\geq 2$ yrs) (Table 9). Chi-square tests indicated differences $(P<0.01$ ) among all classes of deer but indicated no significant differences among all classes of females $(P=0.18)$. Individual contrasts ( $Z$-tests) indicated that all differences between females and adult males were significant $(P \leq 0.04)$.

Annually, highest mortality occurred during the general firearms hunting season (16 oct-30 Nov, Fig. 3). Nineteen deaths were documented among radioed deer during 1990-91 in addition to 9 in $1989-90$ and 8 in 1988-89. Of all deaths, 15 


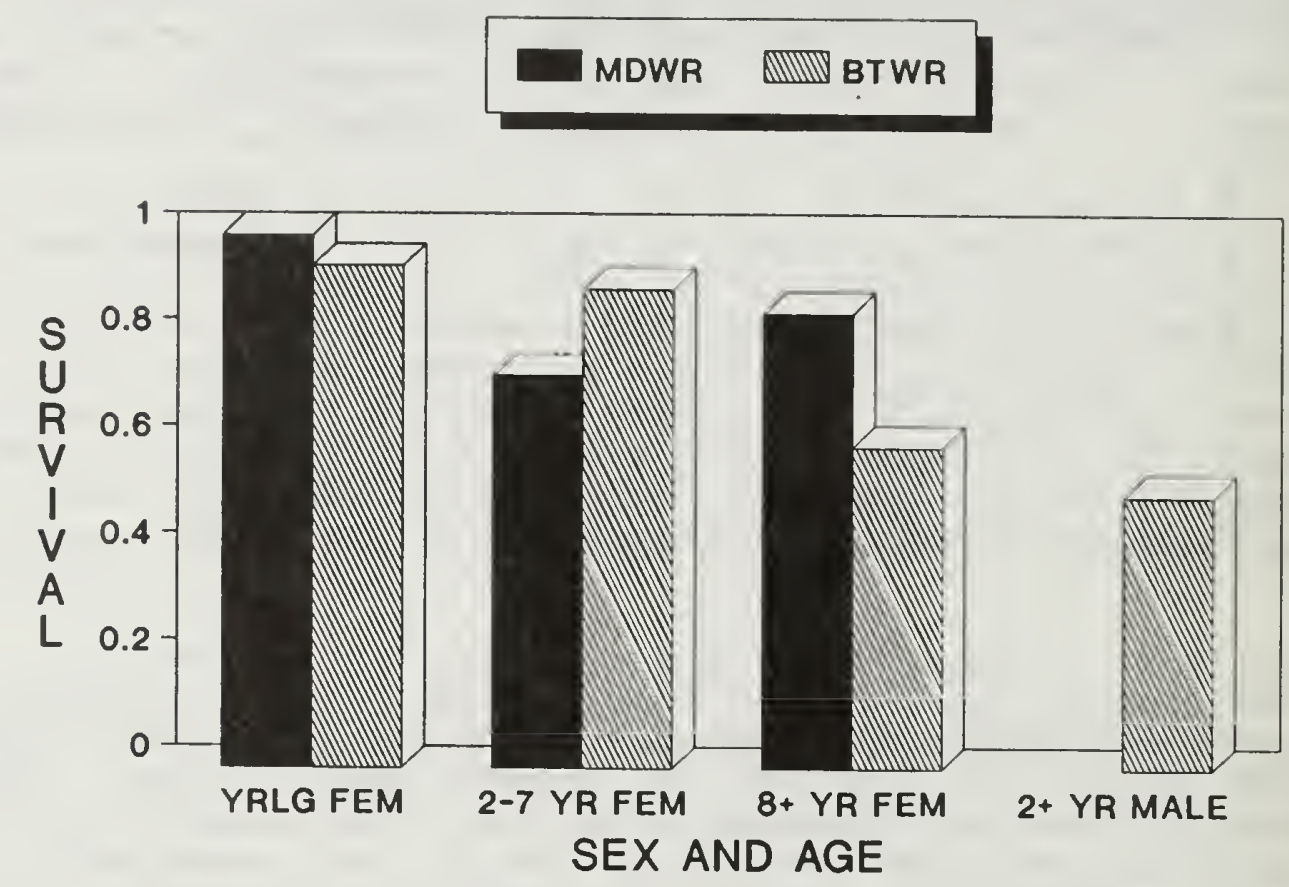

Figure 11. Annual survivorship by sex and age of adult whitetailed deer associated with Bowser-Tally Lakes and Murphy-Dickey Lakes winter ranges for all years combined, 1988-91.

(42\%) were directly attributable to hunting. Among other documented causes, natural mortality and vehicle collisions each accounted for 2 (5\%) deaths. Cause of death was undetermined for 17 (48\%) documented deaths. However, both temporal and spatial circumstances suggested at least 12 of these resulted from natural causes.

Twenty-seven deaths of neckbanded deer were reported during 1988-91 that included 16 (59\%) killed by hunters. Fifteen of these were reported hunter kills; the other died as a result of wounding. Six (22\%) deer were killed by automobiles, 2 (7\%) were killed by dogs, and cause of death for 3 others was undetermined. The difference between documented human-caused and other mortality in samples of radio-collared and neckbanded deer (47 vs. 81\%) probably reflected inability to account for a substantial proportion of natural mortality among neckbanded deer beyond what is readily visible and reported. 
Table 9. Annual survival and cause-speciflc mortality (May-Apr) among radlo-collared white-talled deer from Bowser-Tally Lakes and Murphy-Dickey Lakes winter ranges, 1989-91.

Sex and age

Yrig if

$2-7 \mathrm{yr} \$ 9$

$\geq 8 \mathrm{yr} q 9$

$\geq 2$ yr ơ

No. deer $(\max$.)

27

161

34

27

No. radlo days

4,354

43,771

9,041

5,385

No. deaths

1

17

9

9

Annual Survival

0.948

0.865

0.780

0.499

95\% Cl

$0.854-1000^{\circ}$

0.808-0.927

$0.640-0.952$

$0.317-0.787$

Cause-specific mortality:

Hunting

0.000

0.066

0.000

0.403

Natural

0.000

0.000

0.070

0.000

Vehicle

0.000

0.008

0.000

0.035

Unknown

0.052

0.039

0.149

0.063

apper limit was truncated at $\mathbf{1 . 0 0 0}$

Among radio-collared deer, hunting mortality was documented only in females of ages 2-7 years and in adult ( $\geq 2$ yrs) males of which $7 \%$ and $40 \%$ of the respective classes were harvested. Underrepresentation of yearling females and females of ages $\geq 8$ years also was suggested in sex and age composition of deer examined at check stations (Fig. 6). Their virtual absence in the harvest of radio-collared deer probably reflected a relatively small number of radio-collared deer in these age groups particularly yearlings during autumn. However, these age classes probably were relatively less affected by hunting-related mortality than were those females in age classes 2-7 years. Mortality from causes other than hunting was documented among all ages of females as well as adult males with the extremes ranging from $5 \%$ among yearling females to $22 \%$ among females $\geq 8$ years of age. However, chi-square tests indicated that differences with regard to sex and age were not significant $(P=0.23)$. 
Yearlong Distribution and Movements

The extent and timing of movement by radio-collared deer off both winter ranges (BTWR and MDWR) in late March-early April 1991 to transitional and summer ranges followed the pattern described for the 2 preceding years (Dusek and Morgan 1990) and by Mundinger and Riley $(1982,1983)$ during the early 1980's. Distance between geographical centers of activity for winter and summer home ranges varied from 23 to $31 \mathrm{~km}$ (Dusek 1989). Major areas of concentration during late spring through autumn for deer associated with BTWR included both Good Creek and Star Meadows in the Tally Lake District. As during previous years, most deer associated with MDWR occupied the Fortine Creek drainage including second and third order drainages during April-November. The meadow area at the confluence of Swamp and Lake Creeks was a major concentration area during late May as was Star Meadows. These movement and distributional patterns suggest 2 discrete herd units associated with the respective winter ranges (Fig. 12). Martin Creek was used by a few individuals from each winter range.

Dates of arrival and departure on BTWR were estimated from 33 and 46 radio-collared deer in 1990 and 1991, respectively. Autumn migrants occupied BTWR an average of 98 days in 1989-90 and 125 days in 1990-91. Fourteen radio-collared autumn migrants at MDWR occupied the winter range for an average of 120 days in 1990-91. Most deer occupied the respective winter ranges from early-to-mid December 1990 through early April 1991.

\section{RATIONALE FOR AN EXPERIMENTAL HUNTING BEABON}

Harvest management for deer has been largely predicated on the concept of a "shootable surplus", and as most often applied, assumes that deer populations are inherently irruptive and limited by winter forage (Mackie et al. 1990). The concept also assumes that winter carrying capacity $(K)$ is stable and that removal of a "harvestable surplus" increases per capita forage availability thereby increasing survivability of remaining individuals over winter in a compensatory manner. While acknowledging the potential for density-dependent phenomena to occur, experimental evidence suggests that broad application of the concept may not be the most pragmatic approach to management (Mackie et al. 1990). Experimental evidence suggested huntingrelated mortality was additive to natural mortality among adult female deer in an eastern Montana population (Dusek et al. 1989).

Design of the current deer research project lends itself to addressing these questions by using a portion of the area as a control in which antlerless deer are harvested to a lesser extent than in the treatment area; both areas are simultaneously 


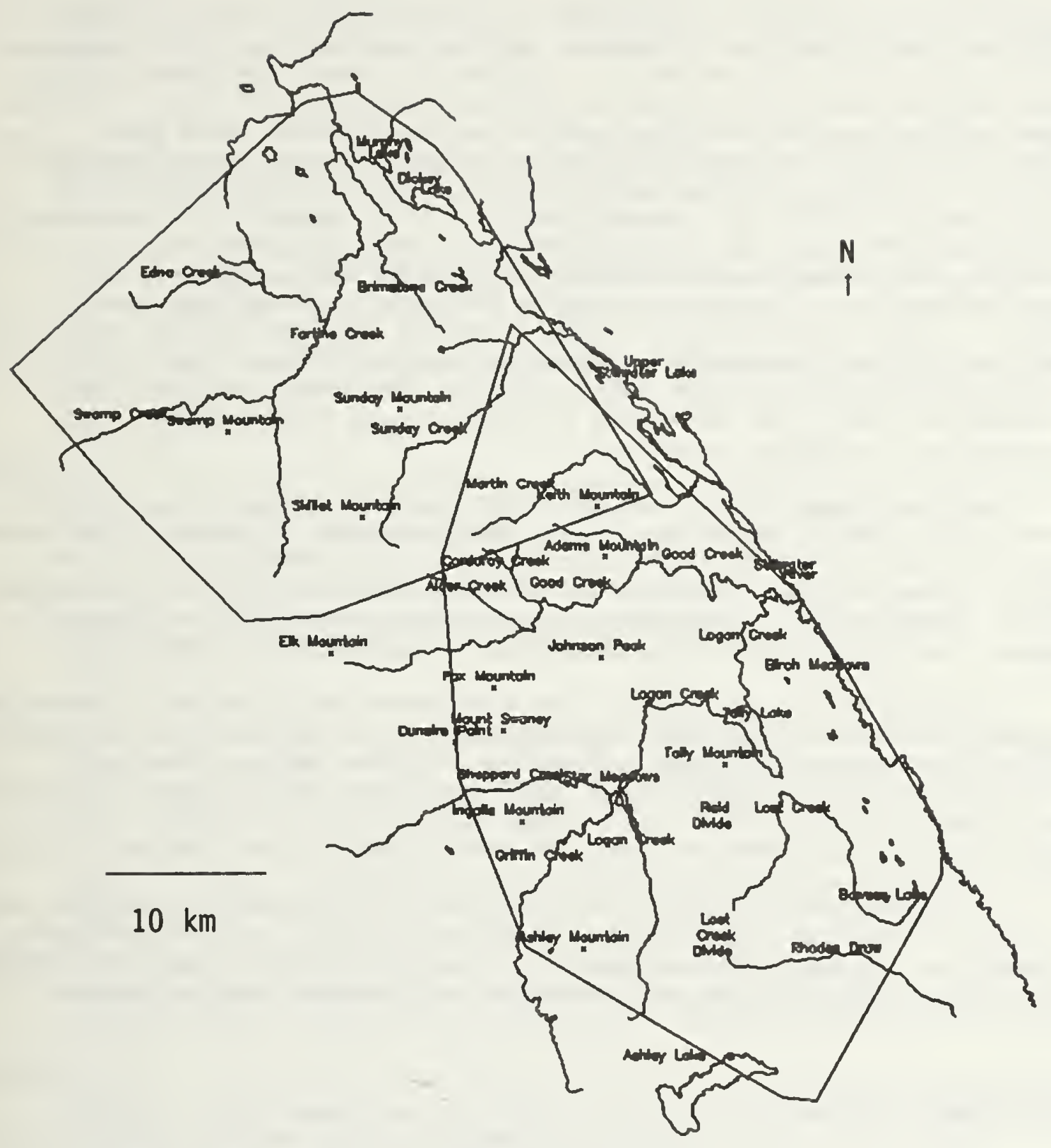

Figure 12. Yearlong distribution of whitetail herd units on Fortine and Tally Lake Ranger Districts, June 1990-May 1991. 
subjected to the same environmental variables. Manipulative studies involving perturbations of the system with both temporal and spatial controls offer a rigorous approach to determining cause and effect relationships (White and Garrott 1990). Three years of survival/mortality and other population data are summarized in this report prior to initiating an experimental hunting season. Control and treatment areas include hunting districts 101 and 102, respectively. Each appears to represent a discrete herd unit in the Salish Range but yet similar in climate, topography, vegetation, and land use. Harvest regulations have been the same in both units over the past 3 years. Annual survival of adult females did not differ over a 3year period, although the sample of radio-collared deer in hunting district 101 was rather small. However, significant differences were not observed between areas among other population variables examined.

Harvest regulations in hunting district 101 , the control area, will remain unchanged from the previous 3 years. The same regulations will affect the A-tag as in the remainder of the region (1st 15 days either-sex and the remainder antlered bucks only). This still represents a somewhat conservative harvest regime to be compared with one that is moderately liberal.

Hunting District 102 is the treatment unit in which doubling current antlerless harvest levels will be attempted by issuing antlerless B-tags through a drawing (600 in 1991). Harvest mortality among adult females (2-7 yrs) was $7 \%$ compared to total annual mortality of 16\%. Proposed regulations for the A-tag would remain the same as for the remainder of the region.

A monitoring strategy will generally follow that of the past 3 years including trapping and marking, aerial radio-tracking, examining hunter-killed animals at check stations, and monitoring population composition and trend using indexes and estimates (Dusek and Morgan 1990).

\section{LITERATURE CITED}

Clover, M. R. 1954. A portable deer trap and catch net. Calif. Fish and Game 40:367-373.

Davis, D. E. 1982. Calculations used in census methods. Pp. 344-369 in D. E. Davis, ed. Handbook of census methods for terrestrial vertebrates. CRC Press, Inc., Boca Raton, FL.

Dusek, G. L. 1989. Population ecology of white-tailed deer in northwestern Montana. Job Prog. Rep., Mont. Dep. Fish, Wildl. and Parks, Helena. Fed. Aid Proj. W-100-R-2. $26 \mathrm{pp}$. 
and J. T. Morgan. 1990. Population ecology of whitetailed deer in northwestern Montana. Job Prog. Rep., Mont. Dep. Fish, Wildl. and Parks, Helena. Fed. Aid Proj.W-100R-3. $47 \mathrm{pp}$.

and R. D. Mace. 1991. Application of remote photography surveys to ungulate research and management, in L. J. Lyon, ed., Elk vulnerability -- a symposium. In press.

, R. J. Mackie, J. D. Herriges, Jr., and B. B. Compton. 1989. Population ecology of white-tailed deer along the lower Yellowstone River. Wildl. Monogr. No. 104. 68 pp.

Gilbert, F. F. 1966. Aging white-tailed deer by annuli in the cementum of the first incisor. J. Wildl. Manage. 30:200202 .

Heisey, D. M., and T. K. Fuller. 1985. Evaluation of survival and cause-specific mortality rates using telemetry data. J. wildl. Manage. 49:668-674.

Longhurst, W. M., and G. E. Connolly. 1982. Deer (pellet count). Pp. 247-248 in D. E. Davis, ed. Handbook of census methods for terrestrial vertebrates. CRC Press, Inc., Boca Raton, FL.

Mace, R., T. Manley, and K. Aune. 1990. Use of systematically deployed remote cameras to monitor grizzly bears. Job Prog. Rep., Mont. Dep. Fish, Wildl. and Parks, Helena. 25pp.

Mackie, R. J., K. L. Hamlin, D. F. Pac, G. L. Dusek, and A. K. Wood. 1990. Compensation in free-ranging deer populations. Trans. N. Am. Wildl. and Nat. Res. Conf. 55:518-526.

Minta, S., and M. Mangel. 1989. A simple population estimate based on simulation for capture-recapture and captureresight data. Ecol. 70:1738-1751.

Mundinger, J. G., and S. J. Riley. 1982. Population ecology and habitat relationships of white-tailed deer in coniferous forest habitat of northwestern Montana. Pp. 50-66 in Montana deer studies. Job Prog Rep., Mont. Dep. Fish, Wildl. and Parks, Helena. Fed. Aid Proj. W-120-R-13.

, and

1983. Population ecology and habitat relationships of white-tailed deer in coniferous forest habitat of northwestern Montana. Pp. 49-63 in Montana deer studies. Job Prog Rep., Mont. Dep. Fish, Wildl. and Parks, Helena. Fed. Aid Proj. W-120-R-14. 
Nelson, M. E. and L. D. Mech. 1986. Mortality of white-tailed deer in northeastern Minnesota. J. Wildl. Manage. 50:691698 .

Peek, J. M., R. J. Mackie, and G. L. Dusek. 1990. Over-winter survival strategies of North American cervidae. Proc. Int. symp. on Moose, Syktyvkar, U.S.S.R. 3 : In press.

Pfister, R. D., B. L. Kovalchick, S. F. Arno, and R. C. Presby. 1977. Forest habitat types of Montana. USDA, Forest Service, Gen. Tech. Rep. INT-34. 174 pp.

Rogers, L. L. 1987. Seasonal changes in defecation rates of free-ranging white-tailed deer. J. Wildl. Manage. 51:330-333.

Sauer, J. R., and B. K. Williams. 1989. Generalized procedures for testing hypotheses about survival or recovery rates. J. wildl. Manage. 53:137-142.

Sawyer, T. G, R. L. Marchinton, and W. MacLentz. 1990. Defecation rates of female white-tailed deer in Georgia. wildl. Soc. Bull. 18:16-18.

Severinghaus, C. W. 1949. Tooth development and wear as criteria of age in white-tailed deer. J. Wildl. Manage. $13: 195-216$.

Smart, C. W., R. H. Giles, Jr., and D. C. Guynn. 1973. Weight tape for white-tailed deer in Virginia. J. Wildl. Manage. $37: 553-555$.

Swenson, J. E., and S. T. Stewart. 1982. On the use of population condition indices in deer management. Pp. 28-35 in C. D. Eustace, ed. Practical application of recent research. Proc. Montana Chapt., The wildl. Soc., Billings.

White, G. C., and R. A. Garrott. 1990. Analysis of wildlife radio-tracking data. Academic Press, Inc., San Diego, CA. $383 \mathrm{pp}$.

Wood, A. K., R. E. short, E. A. Darling, G. L. Dusek, R. G. Sasser, and C. A. Ruder. 1986. Serum assays for detecting pregnancy in mule and white-tailed deer. J. Wildl. Manage. $50: 684-687$.

Submitted by: Gary L. Dusek 
Summer habitat use of white-tailed deer on the Tally Lake Ranger District of the Flathead National Forest

\section{JOB OBJECTIVES:}

1. Determine season long and diel activity and habitat use patterns of white-tailed deer on summer ranges on the Tally Lake Ranger District of the Flathead National Forest.

2. Determine use and importance of various seral stages of coniferous forest and riparian communities and how spatial distribution of these communities to form habitat complexes influences distribution and abundance of deer.

3. Determine the importance of various habitat features such as: slope, aspect, elevation, vegetative structure and species composition of forest stands, and distance to cover, riparian areas, and roads.

\section{INTRODUCTION}

White-tailed deer summer use of coniferous forest in northwest Montana has been studied previously by Leach (1982), Mundinger (1984), and Krahmer (1989). The Tally Lake District northwest of Kalispell, initially studied in the early 1980's, is an important whitetail summer range (Mundinger and Riley 1982, 1983). However, extensive timber harvesting and road building on the district could potentially disrupt traditional patterns of whitetail activity and habitat use on summer ranges.

This study was initiated to investigate whitetail activity and habitat use while deer occupy summer and transitional ranges on the Tally Lake District as well as diel patterns during that period. This report describes research activities during the second of 3 summer field seasons (1 May-30 November 1990). Major efforts during the period concentrated on trapping deer to increase the number of radio-collared animals in specific areas, and relocating radio-collared deer through aerial surveys and 24hr telemetry sessions. Other activities included: experimental camera surveys to determine habitat use and population characteristics, deer collections for food habits information, and habitat assessment through IANDSAT imagery and ground plots.

\section{STUDY AREA}

The Tally Lake District has been described previously by Mundinger and Riley (1982) and Dusek (1989). My study area includes that portion of the district containing all deer 
relocations and outlined by major physiographic points north of Ashley Mountain, east of the Flathead/Lincoln County Line, south of Martin Falls, and west of Tally Lake.

The study area drains to the northeast into the stillwater River via Good, Logan, and Martin Creeks (Fig. 1). Elevation ranges from $1020 \mathrm{~m}$ at Tally Lake to $1935 \mathrm{~m}$ on Mount Swaney. Subalpine fir/queen cup beadlilly (Abies lasiocarpa/Clintonia uniflora) is the major habitat type (Pfister et al. 1977) throughout the study area. However, habitat alteration through logging, cattle grazing, and natural fires has produced a forest which is a mosaic of mature mixed conifer, large stands of lodgepole pine (Pinus contorta), new clearcuts, various stages of regrowth, riparian meadows, and other natural openings.

Major species present in the overstory include lodgepole pine, Douglas-fir (Pseudotsuga menziesii), subalpine fir (Abies lasiocarpa), and western larch (Larix occidentalis). Common grass, forb, and shrub species include pine grass (Calamagrostis rubescens), timothy (Phleum pratense), strawberry (Fragaria virginiana), yarrow (Achillea millefolium), arnica (Arnica spp.), beargrass (Xerophyllum tenax), mountain-lover (Pachistima myrsinites), spiraea (Spiraea betulifolia), rose (Rosa gymnocarpa), twinflower (Linnaea borealis), buffaloberry (Shepherdia canadensis), alder (Alnus spp.), willow (Salix spp.), snowberry (Symphoricarpus albus), and huckleberry (Vaccinium spp.).

Two areas which support large numbers of deer throughout the summer are the Star Meadows complex formed by the confluence of Logan, Griffin, and Sheppard Creeks; and the Alder, Corduroy, Good Creek complex. Star Meadows is approximately $65 \mathrm{~km}^{2}$. Onethird of which is the meadow bottom, a mixture of open meadowlands, willows, and scattered timber. The slopes of the complex are a mosaic of timber and cutover areas. The Alder, Corduroy, Good Creek Complex is about half the size of Star Meadows. Contrastingly, the area primarily consists of large stands of 60-70 year old lodgepole pine, a remnant of large fires during the early part of this century. This complex lacks large meadows but a number of small wet meadows are associated with each drainage.

\section{METHODS}

Deer relocations were obtained via fixed-wing aircraft surveys, 24-hr telemetry sessions using 3 truck mounted null antennae arrays, remote cameras, and visuals either incidental or purposely obtained. Test transmitters were placed at known locations to check accuracy of relocation procedures. Date, time, and UTM coordinates were recorded for each relocation and plotted on aerial photographs and/or topographic maps. 


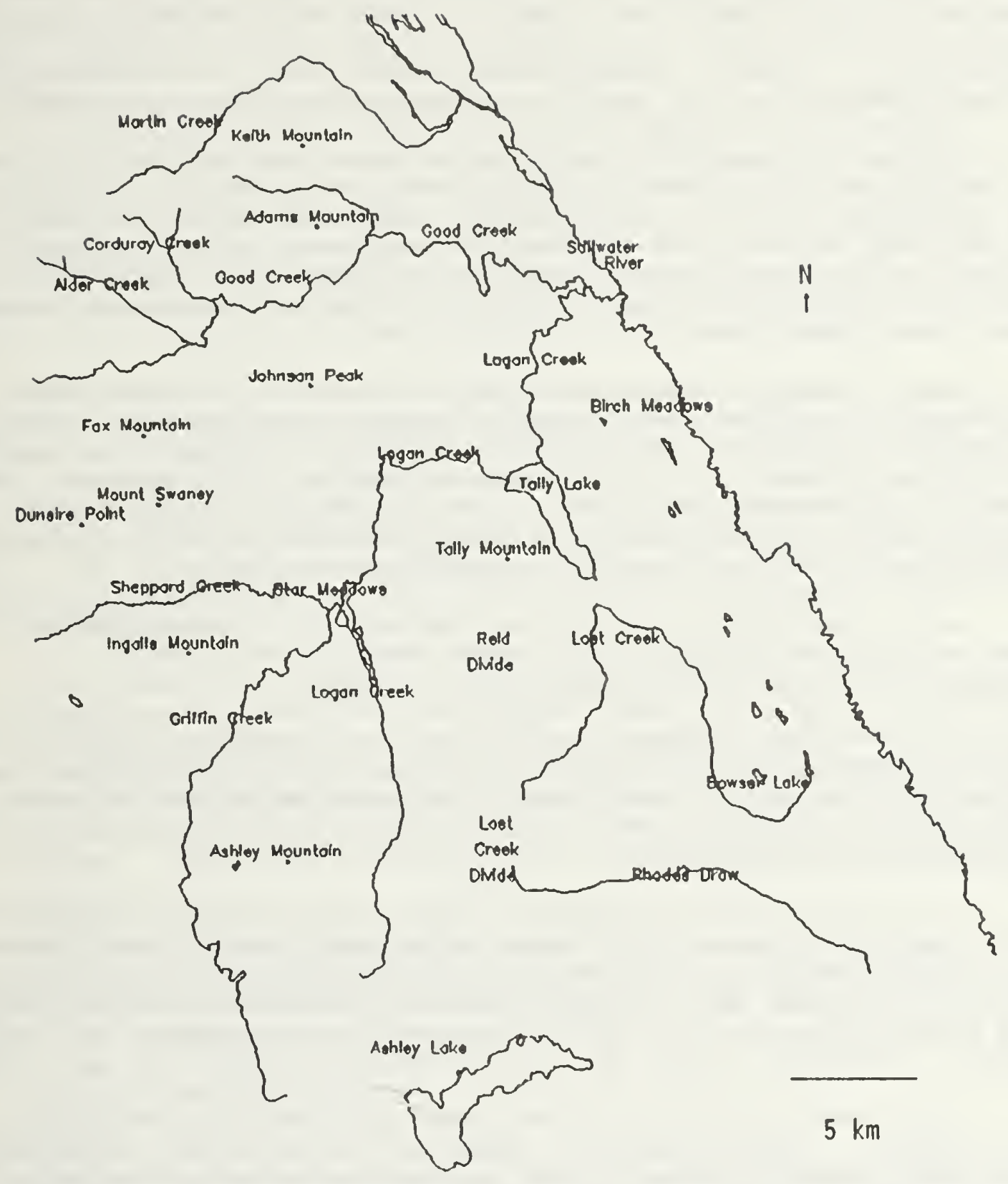

Figure 1. Tally Lake deer project study area, Tally Lake Ranger District, Flathead National Forest. 
Streams, lakes, and prominent peaks were digitized using program CAPTURE (Univ. Ga. 1987). These data as well as aerial and ground relocations were plotted using program SURFER (Golden Software Inc. 1988). Summer home ranges were calculated using program TELEM (Coleman and Jones 1986) and plotted separately.

Summer trapping following procedures similar to 1989 (Dusek and Morgan 1990). Three trapping sessions were held during spring/summer 1990 to increase the number of radio-collared deer in the Star Meadows and Corduroy Creek areas. One to four clover traps (Clover 1954) baited with salt blocks were used during each session. Tagging and handling followed procedures previously described (Dusek 1989).

Camera surveys were conducted in the star Meadows area in May and in Griffin creek alone in August and September. Ten cameras were used for each session. Sites were selected randomly at the macrolevel, i.e., drainage or quadrat. At the microlevel cameras were placed adjacent to well used deer trails. All photographs were analyzed for animal species present, number of individuals, and sex and age class where possible.

Seven photoplots ( 5 at Star Meadows and 2 at Corduroy Creek) were set up and pictures were taken monthly to record phenological changes throughout the summer.

Fifty aerial relocations of radio-collared deer were randomly selected and visited on the ground. Information was recorded on habitat type, vegetative species present at each strata of the forest, horizontal and vertical cover, and topographic information.

At the macrolevel LANDSAT imagery and program ERDAS was used to attempt to separate the study area into vegetative classes. A supervised classification system was used where I selected known vegetative types (e.g., new clearcut or mature mixed conifer) and the program extrapolated these selections throughout the study area.

Deer were collected twice monthly to obtain food habits information. Approximately 1 quart of rumen sample was taken from each deer collected. Samples were cleaned and sorted at the wildlife research lab in Bozeman. Materials were analyzed macroscopically using a reference collection. Percent abundance and volume of each species present was recorded.

\section{RESULTS and DISCUS8ION}

Fifty-seven radio-collared deer were monitored during all, or a portion, of spring-autumn 1990 yielding 885 summer and 111 transitional relocations (Appendix Table 1). Information was 
obtained on summer distribution and home range, habitat use, and migration patterns.

\section{Distribution}

Summer distribution showed clustering of deer in certain parts of the study area with little documented use elsewhere (Fig. 2). Thirty deer used the northern portion of the study area bounded on the north by Martin creek and on the south by Johnson Peak and Fox Mountain. These deer primarily used the Good Creek bottom and south facing slopes as a travel corridor and transitional area, moving to higher elevations as the snow melted. Twelve deer summered in the Alder, Corduroy, Good Creek complex and 7 deer in the Adams Mountain/Miller Creek area.

Twenty-seven deer summered in the southern portion of the study area primarily around the star Meadows complex. Nine deer used the north side of Star Meadows between Logan and Sheppard creeks and 9 used the south side along Griffin creek. Initially, many deer around star Meadows restricted their movements to the south facing slopes as much of the bottom is flooded during the spring. In June many deer made use of the meadow for foraging and fawning retreating back to the slopes as the meadow dried out later in the summer.

Elevational use by deer during the summer ranged from $1100 \mathrm{~m}$ at the confluence of Miller and Goods Creeks to $1600 \mathrm{~m}$ near the peak of Adams Mountain with some intra-seasonal movement. Little use was made of uplands exceeding $1600 \mathrm{~m}$ within the center of the study area, the sylvia Lake/Hand creek area in the southeast, the upper portions of Logan Creek, or the lower portions of Logan and Good creeks. The latter however were used as transitional areas.

\section{Home Range}

Once deer arrived on their summer home ranges there was very little movement until fall migration (Fig. 3). Summer home ranges of the 46 deer for which I recorded more than 10 relocations averaged 103.2 ha $( \pm 13.0$ [SE]). Home ranges for the 7 males and 39 females averaged $245.6 \mathrm{ha}( \pm 48.3$ [SE]) and $77.7 \mathrm{ha}$ $( \pm 7.6[\mathrm{SE}])$, respectively.

\section{Habitat Use}

Figure 3 illustrates an association of whitetails with riparian areas. The home range of almost every deer encompassed a creek bottom. Many creeks only flow intermittently or move underground for part of their course. However, for the most part they are mesic sites as are areas within the home ranges of those deer not associated with a specific creek.

A vegetation cover map of the study area is being created with the aid of Landsat imagery and the Forest Service's ERDAS system. Through general observations however, it should be noted that most individual deer relocations fell in timbered areas although often bordering 


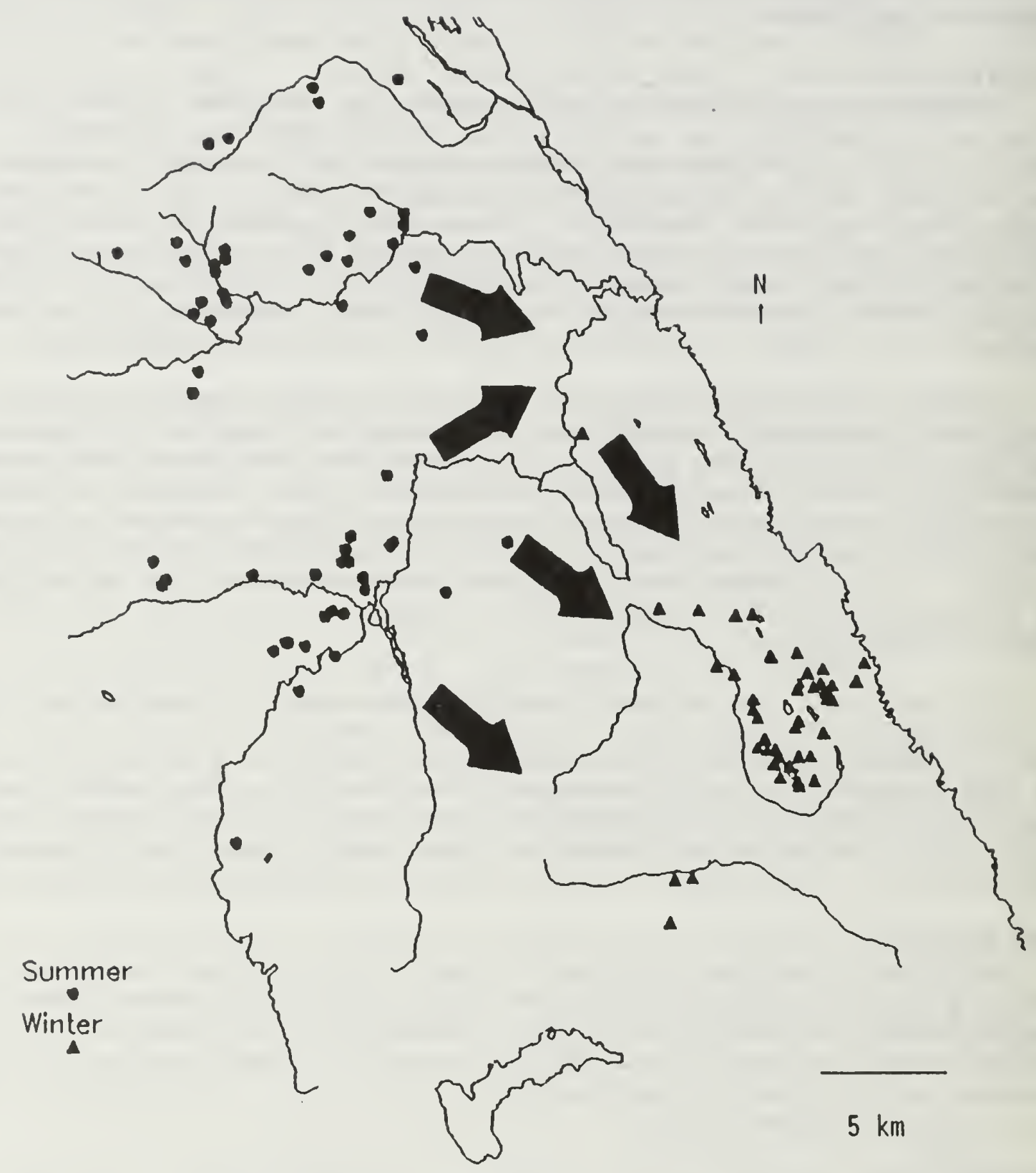

Figure 2. Seasonal activity centers and major migration routes of white-tailed deer, summer 1990 - winter 1991. 


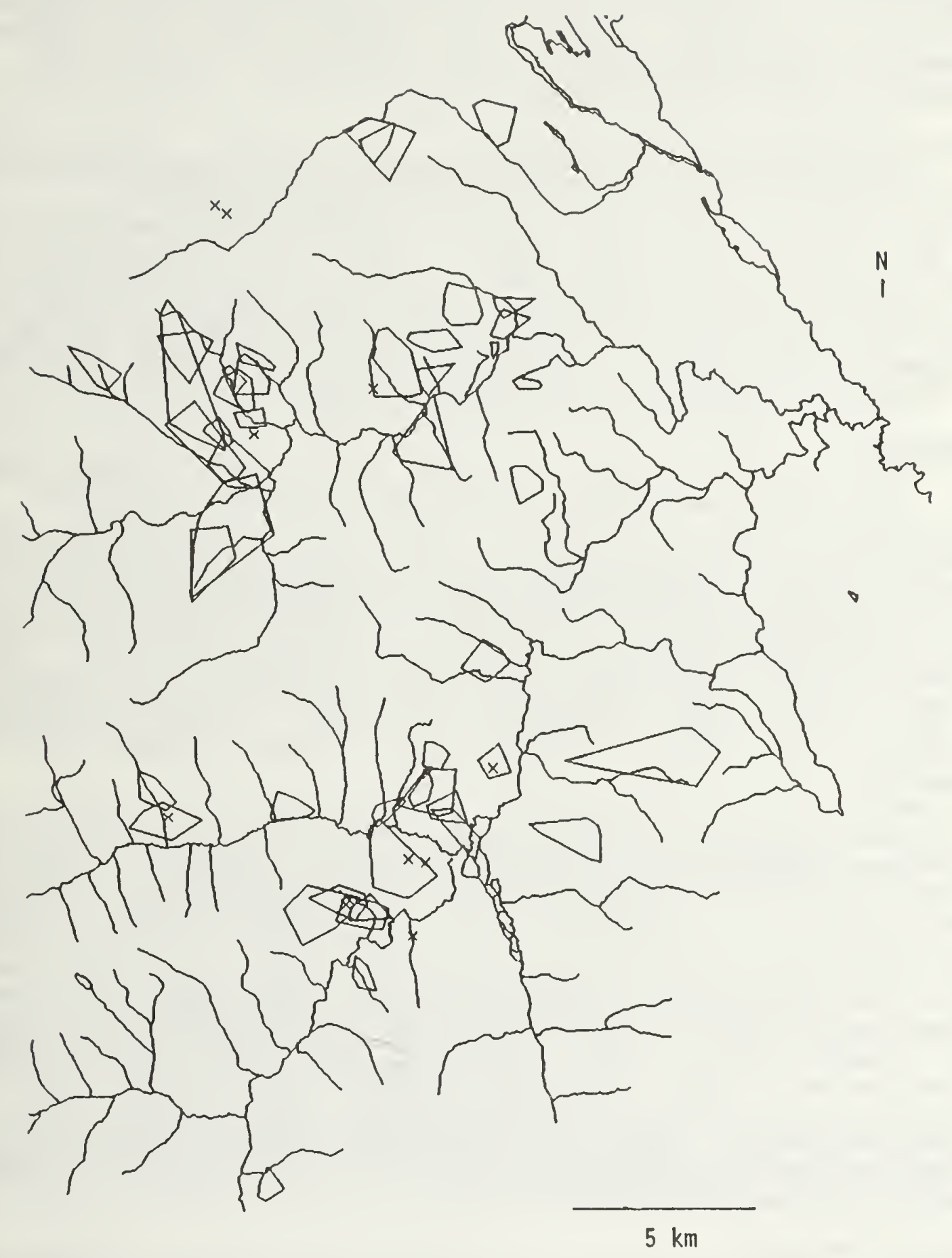

Figure 3. Home range locations ( $\mathrm{X}=$ deer with $<10$ relocations) of 57 deer monitored on the Tally lake District, summer 1990 . 
another type including cutover areas. On the larger scale summer home ranges of individual deer encompass areas of mixed timber, stands of lodgepole, cutover, and riparian areas. The complex of vegetation communities along with topographic features may determine deer distribution.

\section{Diel Patterns}

Twenty-four hour telemetry sessions were conducted once each at Star Meadows and Corduroy Creek in April and May, respectively. Thereafter sessions occurred twice monthly (once at each site) through september. Usable data were obtained for 5-9 deer in Corduroy Creek and 7-16 deer on the north side of star Meadows and Griffin Creek. The number of deer varied as they moved on and off the areas during migration and as deer were trapped in the summer. Night locations of deer have been shown to increase overall home range size (Dusek et al. 1989).

\section{Migration}

In general, migration patterns were similar to 1989 (Figure

2). Deer from star Meadows moved off the summer range to transitional areas or directly to the winter range earlier than deer from the Good Creek area. The 4 radio-collared deer which used the lower Logan Creek portion of Star Meadows were the first to move off the bottom. One deer that moved from Logan creek to Tally Mountain in July in 1989 made the same move in June in 1990 after spending less than 2 months on the meadow bottom. The other 3 moved to Tally Mountain, upper Reid Creek, and directly to the winter range, in August. Only 1 deer from the northern portion of the study area moved off its summer range before October.

More numerous flights during fall migration in 1990 allowed a better indication of transitional areas. Similar to 1989 deer summering in the northern portion of the study area travel down Good Creek to its confluence with Logan Creek (Fig. 2). Along this portion of the drainage the topography is less severe and from here deer could move across short, Round, and Birch Meadows to winter ranges in the Bowser, Kuhn's, Pete Ridge area. Deer summering in the southern portion of the study area including star Meadows moved either around the north end of Tally Lake and down the west side, over Tally Mountain and along the east side of the lake, or over the Reid and Lost Creek Divides to get to wintering areas. Important transitional areas include Tally Mountain, Tobie Creek/Stove Pipe Canyon, and the area between lower Logan and Good Creeks.

\section{summer Trapping}

Summer trapping was as efficient (trap nights/deer captured) as winter trapping (Morgan and Dusek 1992). While the effectiveness of trapping to increase numbers of radio-collared deer in specific areas was much better during summer trapping. Deer trapped on winter range dispersed over the entire study 
area, while most of those trapped on summer range remained in the area where captured.

Seventeen deer were captured during 47 trap nights (TN) over 3 trapping sessions conducted during spring/summer 1990. Radio collars were put on 12,7 in the star Meadows area and 5 in Corduroy creek. Nine of the 12 remained in the area where captured thus increasing the number of radio-collared deer in these areas of intensive study.

\section{Camera surveys}

Photographs were recorded of 478 white-tailed deer throughout the 3 sessions. Approximately $65 \%$ were adult deer, 25\% were fawns, and the remainder could not be classified. Eighty-four percent of the adult deer photographed were females, $12 \%$ were males $>1 \mathrm{yr}$, and $6 \%$ were yearling males. Twelve different marked deer were photographed including 5 radioed animals. Photos also were recorded of 2 elk, a coyote, a badger, and cattle.

\section{Habitat Plots}

While only 50 habitat plots were analyzed, data provided vegetative and topographic information from areas of deer use. The habitat type for 31 of 50 plots were in the subalpine fir series. Most of these were in the queencup beadlilly or twinflower habitat type. Fourteen of 50 were on private land or areas not typed. The remaining 5 were in the Douglas-fir or grand fir series.

Primary vegetation was classified as mature mixed conifer at 20 of 50 locations, young mature lodgepole pine with a closed canopy at 10, pole/young mature size lodgepole pine with an open canopy at 13, shrub/sapling at 5, and recent cutover areas at 2 locations. Particular species found in plots are those listed earlier in this report.

Elevation of plots varied from $1160 \mathrm{~m}$ to $1620 \mathrm{~m}$ (mean $=1347$ m). Slope varied from level ground to $45 \%$ (mean = 18\%). Orientation of plots was in all directions, however, southerly to easterly aspects were most prevalent.

Cover was measured using a modified version of the vegetation profile board (Nudds 1977). Cover was recorded at 0.5 $\mathrm{m}$ intervals from 0.0-2.0 m. Horizontal cover averaged in the 20$40 \%$ range at the $0.0-1.0 \mathrm{~m}$ interval and 0-20\% at the $1.0-2.0 \mathrm{~m}$.

\section{Food Habits}

Sixteen rumens (14 collected, 1 trap mortality, 1 hunter harvest) provided information on deer food habits (Appendix Table 2). In general deer on the district were browsers, particularly in the fall (Fig. 4). Browse species were found in all rumens during all seasons studied. Pachistima was used heavily in the 


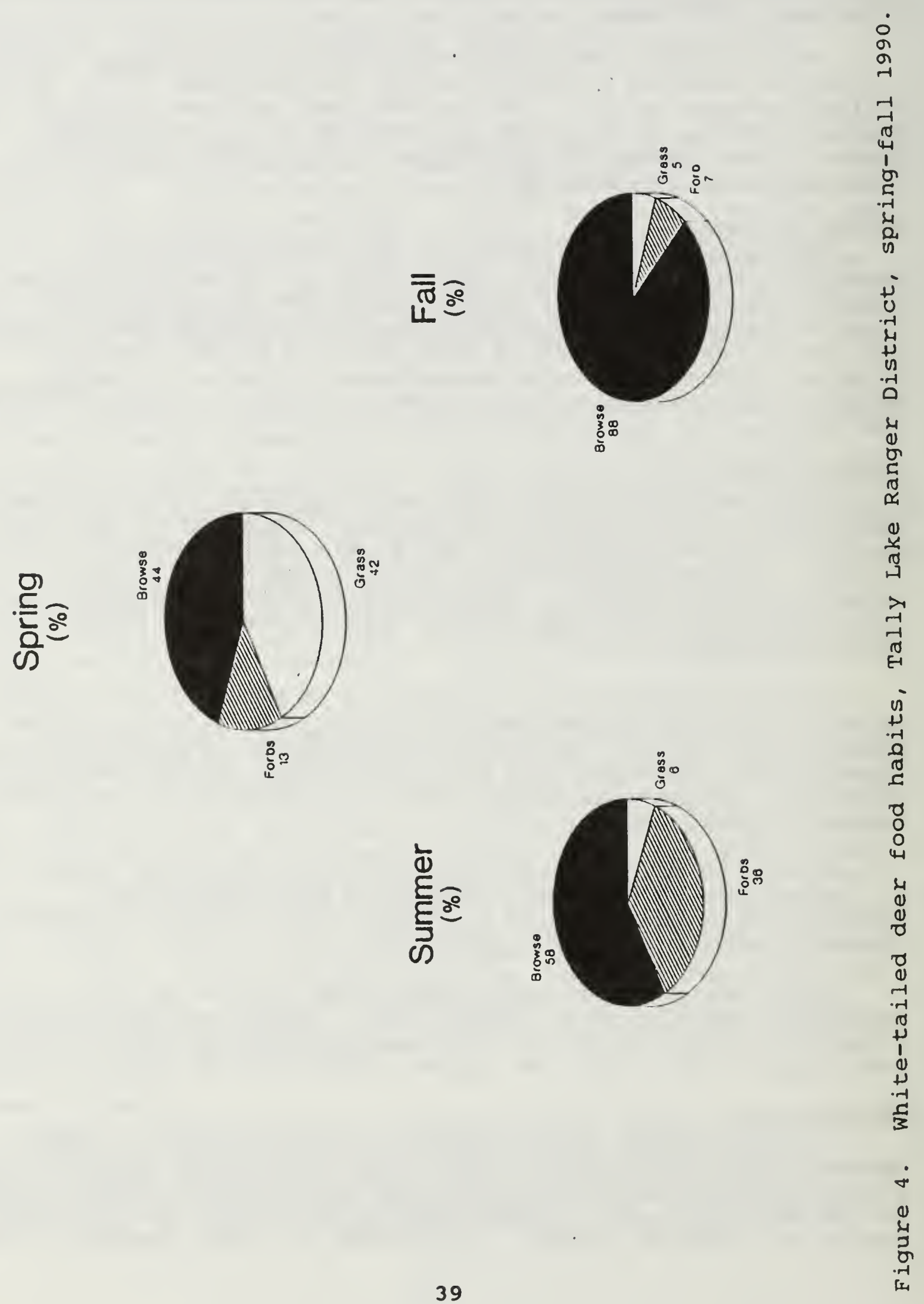


spring and fall and willow was used in the summer. Grass was used primarily in the spring with forbs replacing grass in the summer.

To a large extent food habits followed the plant species found in habitat plots. For instance pachistima was present in 17 of 50 habitat plots and also was a prominent food item. Prince's pine, spiraea, and kinnikinnick also were present in many habitat plots and rumen samples. Species which were abundant on the ground but not in rumen samples were buffalo berry and the vaccinium species.

\section{FOTORE WORK}

During the summer 1991 field season, emphasis will still be on obtaining deer relocations. The schedule of aerial

relocations and twenty-four hour monitoring sessions should remain near the 1990 level.

Because of impending timber harvest in the corduroy creek area more emphasis will be place on that drainage. Summer trapping will be conducted at corduroy creek to increase the number of radio-collared deer in the area. An intensive camera session also will be conducted in corduroy creek drainage to help estimate population size and habitat use of deer in the area.

Other work for 1991 will involve restarting development of a vegetative cover map using LANDSAT imagery and ERDAS as well as working with other GIS layers.

\section{LITERATURE CITED}

Clover, M. R. 1954. A portable deer trap and catch-net. Calif. Fish and Game J. 40:367-373.

Coleman, J. S. and A. B. Jones. 1988. User's guide to Telem88: Computer analysis system for radio-telemetry data. Dept. Fish. and Wildl. , VPI\&SU, Blacksburg, Va. $49 \mathrm{pp}$.

Desktop Digitizing Package. 1988. Center for Remote Sensing and Mapping Center. Univ. Ga., Athens. $31 \mathrm{pp}$.

Dusek, G. L. 1989. Population ecology of white-tailed deer in northwestern Montana. Job Prog. Rep., Fed. Aid Proj. W100-R-2. Mont. Dept. Fish, Wildl, and Parks, Helena. $26 \mathrm{pp}$.

, R. J. Mackie, J. D. Herriges, and B. B. Compton. 1989. Population ecology of white-tailed deer along the lower Yellowstone River. Wildl. Monogr. 104. 68pp. 
and J. T. Morgan. 1990. Population ecology of whitetailed deer in northwestern Montana. Job Prog. Rep., Fed. Aid Proj. W-100-R-3. Mont. Dept. Fish, wildl., and Parks, Helena. $47 \mathrm{pp}$.

and A Camera system to evaluate population parameters and spatial relationships of deer. Proc. Intl. wildl. and Nat. Res. Cong. 3:In press.

Krahmer, R. W. 1989. Seasonal habitat relationships of whitetailed deer in the coniferous forests of northwestern Montana. M.S. Thesis, Univ. Montana, Missoula. $104 \mathrm{pp}$.

Leach, R. H. 1982. Summer range ecology of white-tailed deer in the coniferous forests of northwestern Montana. M.S. Thesis, Univ. Montana, Missoula. $80 \mathrm{pp}$.

Morgan, J. T. and G. L. Dusek. 1992. Trapping white-tailed deer on summer ranges. Wildl. Soc. Bull. 20:In press.

Mundinger, J. G. 1984. Biology of the white-tailed deer on the coniferous forest of northwestern Montana. Pp. 275-284 in W. R. Meehan, T. R. Merrell, Jr., and T. A. Handley, eds. Proc. Fish and wildlife Relationships in Old Growth Forests. symp. Am. Inst. Fish Res. Biol.

and S. J. Riley. 1982. Population ecology and habitat relationships of white-tailed deer in coniferous forest habitat of northwestern Montana. Pp. 50-66 in Montana deer studies. Job Prog. Rep., Fed. Aid Proj. W-120-R-13. Mont. Dept. Fish, Wildl. and Parks, Helena.

and 1983. Population ecology and habitat relationships of white-tailed deer in coniferous forest habitat of northwestern Montana. Pp. 49-63 in Montana deer studies. Job Prog. Rep., Fed. Aid Proj. W-120-R-14. Mont. Dept. Fish, Wildl. and Parks, Helena.

Nudds, T. D. 1977. Quantifying the vegetative structure of wildlife cover. Wildl. Soc. Bull. 5:113-117.

Pfister, R. D., B. L. Kovalchick, S. F. Arno, and R. C. Presby. 1977. Forest habitat types of Montana. USDA, Forest Service, Gen. Tech. Rep. INT-34. 174pp.

Surfer Reference Manual. 1988. Golden Software Inc., Golden Co. 
Appendix Table 1. White-tailed deer monitored on the Tally Lake District, summer 1990.

\begin{tabular}{|c|c|c|c|}
\hline Deer Number & Sex & Age & Location \\
\hline $88001^{\circ}$ & $\mathbf{F}$ & 7 & Listle/Sheppard Creeks \\
\hline 88014 & F & 6 & Good/Miller Creeks \\
\hline 88016 & F & 4 & Good Creek/Adams Mountain \\
\hline 88019 & F & 6 & Good/Trixie Creeks \\
\hline 88020 & F & 3 & Martin Creek \\
\hline $88021^{e}$ & F & 6 & Martin Creek \\
\hline $88063^{\circ}$ & F & 10 & Griffin Creek \\
\hline 89070 & F & 4 & Corduroy Creek \\
\hline 89083 & F & 6 & Adams Mountain \\
\hline 89084 & F & 5 & Corduroy Creek \\
\hline 89087 & F & 5 & Logan Creek \\
\hline 89089 & M & 4 & Alder Creek \\
\hline 89092 & F & 9 & Alder Creek \\
\hline 89095 & M & 3 & Fox Mountain \\
\hline 89096 & F & 3 & Alder Creek \\
\hline 89098 & F & 6 & Good/Miller Creeks \\
\hline $89099^{\circ}$ & M & 5 & Listle Creek \\
\hline 89100 & F & 4 & Fox Mountain \\
\hline 89117 & F & 3 & Adams Mountain \\
\hline 89119 & F & 5 & Corduroy Creek \\
\hline 89124 & F & 3 & Adams Mountain/Miller Creek \\
\hline $89134^{\circ}$ & $\mathbf{F}$ & 10 & Corduroy Creek \\
\hline 89148 & F & 5 & Logan Creek \\
\hline 89149 & F & 3 & North Evers Creek \\
\hline 89163 & F & 4 & Logan Creek \\
\hline 89188 & F & 4 & Griffin Creek \\
\hline 89189 & F & 5 & Martin Lakes \\
\hline 89195 & $\mathbf{F}$ & 5 & Alder Creek \\
\hline
\end{tabular}


Table 1. continued.

\begin{tabular}{|c|c|c|c|}
\hline Deer Number & Sex & Age & Location \\
\hline 89197 & $\mathbf{F}$ & 8 & Sheppard Creek \\
\hline 89224 & $\mathbf{F}$ & 7 & Good Creek/Adams Mountain \\
\hline 89237 & $\mathbf{F}$ & 3 & Star Face \\
\hline 90243 & $\mathbf{F}$ & 5 & Griffin Creek \\
\hline 90245 & $\mathbf{F}$ & 4 & Griffin Creek \\
\hline 90246 & $\mathbf{F}$ & 2 & Griffin Creek \\
\hline 90252 & $\mathbf{F}$ & 2 & Star Face \\
\hline $90255^{b}$ & $\mathbf{M}$ & 2 & Griffin Creek \\
\hline 90257 & $\mathbf{M}$ & 3 & Sheppard Creek \\
\hline $90263^{d}$ & $\mathbf{F}$ & 2 & Star/Sheppard creeks \\
\hline 90271 & $\mathbf{F}$ & 2 & star Face \\
\hline $90304^{b}$ & $\mathbf{F}$ & 2 & Sanko creek \\
\hline 90310 & $\mathbf{M}$ & 3 & Alder Creek \\
\hline 90314 & $\mathbf{F}$ & 10 & Logan Creek \\
\hline $90326^{b}$ & $\mathbf{M}$ & 2 & Reid Creek \\
\hline 90331 & $\mathbf{F}$ & 5 & Good Creek/Adams Mountain \\
\hline $90388^{c}$ & $\mathbf{F}$ & 10 & Good/Nelson Creeks \\
\hline $90389^{b}$ & $\mathbf{M}$ & 2 & Sheppard Creek \\
\hline 90390 & $\mathbf{F}$ & 2 & Star Face \\
\hline $90392^{d}$ & $\mathbf{M}$ & 1 & Sheppard Creek \\
\hline 91393 & $\mathbf{F}$ & 1 & Griffin Creek \\
\hline $91394^{d}$ & $\mathbf{F}$ & 6 & Griffin Creek \\
\hline 91395 & $\mathbf{F}$ & 9 & Griffin Creek \\
\hline 91396 & $\mathbf{F}$ & 2 & Star Face \\
\hline 91397 & $\mathbf{F}$ & 3 & Corduroy/Martin Creeks \\
\hline $91398^{b}$ & $\mathbf{F}$ & 3 & Corduroy Creek \\
\hline 91399 & $\mathbf{F}$ & 9 & Corduroy creek \\
\hline 91400 & $\mathbf{F}$ & 4 & Corduroy/Martin Creeks \\
\hline
\end{tabular}


Table 1. continued.

\begin{tabular}{lccl}
\hline Deer Number & Sex & Age & Location \\
\hline 91401 & $\mathrm{~F}$ & 3 & Corduroy Creek \\
\hline \hline
\end{tabular}

anied, cause unknown.

bied, hunter harvest.

cDied, mountain lion.

Dropped collar.

'Lost signal. 
Appendix Table 2. Results of white-tailed deer rumen sample analysis for spring-autumn, 1990.

\begin{tabular}{cccccc}
\multicolumn{2}{c}{ Spring $(N=5)$} & Summer $(N=6)$ & Fall $(N=5)$ \\
\hline $\begin{array}{c}\text { Occurrence } \\
(\%)\end{array}$ & $\begin{array}{c}\text { Volume } \\
(\%)\end{array}$ & $\begin{array}{c}\text { Occurrence } \\
(\%)\end{array}$ & $\begin{array}{c}\text { Volume } \\
(\%)\end{array}$ & $\begin{array}{c}\text { Occurrence } \\
(\%)\end{array}$ & $\begin{array}{c}\text { Volume } \\
(\%)\end{array}$ \\
\hline
\end{tabular}

Browse

\begin{tabular}{|c|c|c|c|c|c|c|}
\hline Chimaphila umbellata & 40 & 2 & 33 & 1 & 60 & 29 \\
\hline Spiraea densiflora & 60 & 5 & 17 & $\operatorname{tr}$ & & \\
\hline Pachistima myrsinites & 60 & 13 & 50 & 3 & 100 & 45 \\
\hline Vaccinium spp. & 40 & 3 & 17 & 2 & & \\
\hline Pinus cordata & 60 & 5 & 17 & 1 & & \\
\hline Arctostaphylos uva-ursi & 40 & 1 & 17 & $\operatorname{tr}$ & 20 & $\operatorname{tr}$ \\
\hline Salix spp. & 20 & 6 & 33 & 13 & & \\
\hline Ceanothus spp. & 20 & 2 & 17 & 3 & & \\
\hline Pseudotsuga menziesii & 20 & 1 & 50 & 3 & 100 & 5 \\
\hline Alnus spp. & 20 & 1 & 17 & 2 & & \\
\hline Ribes spp. & 20 & 1 & 17 & 3 & & \\
\hline Amelanchier anifolia & & & 50 & 8 & 40 & 1 \\
\hline Bryoria fremontii & & & 17 & $\operatorname{tr}$ & & \\
\hline Symphoricarpus spp. & & & 17 & 6 & 40 & 3 \\
\hline Juniperus communis & & & 17 & 3 & & \\
\hline Rose spp. & & & 33 & 4 & & \\
\hline Cornus stolonifera & & & 17 & 2 & & \\
\hline Berberis repens & & & & & 20 & 1 \\
\hline Unknown & 20 & 4 & 33 & 4 & 40 & 4 \\
\hline Total & 100 & 44 & 100 & 58 & 100 & 88 \\
\hline \multicolumn{7}{|l|}{ Forb } \\
\hline Irifloium spp. & & & 17 & $\operatorname{tr}$ & & \\
\hline Epilobium anqustifolium & & & 33 & 12 & & \\
\hline Xerophyllum racemosa & & & 17 & 4 & & \\
\hline Antennaria racemosa & & & 17 & 1 & & \\
\hline Arnica spp. & & & 17 & $\operatorname{tr}$ & & \\
\hline Senecio spp. & & & 17 & 6 & 20 & 7 \\
\hline Unknown & 80 & 13 & 17 & 13 & & \\
\hline Total & 80 & 13 & 100 & 36 & 20 & 7 \\
\hline Grass & 100 & 42 & 83 & 6 & 40 & 5 \\
\hline Mushroom & & & & & 40 & $\operatorname{tr}$ \\
\hline
\end{tabular}


Submitted by: John T. Morgan 

